\title{
Plea Bargaining as Contract
}

\author{
Robert E. Scott $\dagger$ and William J. Stuntz行
}

Most criminal prosecutions are settled without a trial. ${ }^{1}$ The parties to these settlements trade various risks and entitlements: the defendant relinquishes the right to go to trial (along with any chance of acquittal), while the prosecutor gives up the entitlement to seek the highest sentence or pursue the most serious charges possible. The resulting bargains differ predictably from what would have happened had the same cases been taken to trial. Defendants who bargain for a plea serve lower sentences than those who do not. ${ }^{2}$ On the other hand, everyone who pleads guilty is, by definition, convicted, while a substantial minority of those who go to trial are acquitted. ${ }^{3}$

There is something puzzling about the polarity of contemporary reactions to this practice. Most legal scholars oppose plea bargaining, finding it both inefficient and unjust. ${ }^{4}$ Nevertheless, most participants in the plea bargaining

$\dagger$ Dean and Lewis F. Powell, Jr. Professor of Law, University of Virginia.

it E. James Kelly, Jr. Research Professor of Law, University of Virginia.

We wish to thank Ken Abraham, Richard Bonnie, Pam Karlan, Paul Mahoney, John Monahan, Paul Stephan, George Triantis, and participants in a workshop at the University of Toronto for helpful comments on earlier drafts. We also thank Alison Grossman for her research assistance.

1. In 1989, 86\% of all federal criminal cases were disposed of without a trial. See U.S. DEP'T OF JUSTICE, SOURCEBOOK OF CRIMINAL JUSTICE STATISTICS 502 tbl. 5.25 (Kathleen Maguire \& Timothy J. Flanagan eds., 1990) [hereinafter 1990 SouRCEBOOK]. The same phenomenon occurs in state cases; in 1988, $91 \%$ of felony convictions in the 75 most populous counties in the United States were obtained through guilty pleas. Id. at 526 tbl. 5.51 .

2. In 1986, among defendants convicted in a state court trial of a serious felony, the average sentence was 145 months; the comparable figure for defendants who pled was 72 months. The difference in median sentences for that same year is not as striking, but nevertheless is substantial: the median for those convicted at trial was 90 months; for those who pled guilty it was 60. U.S, DEP'T OF JUSTICE, SOURCEBOOK OF CRIMINAL JUSTICE STATISTICS 517 (Kathleen Maguire \& Timothy J. Flanagan eds., 1989).

3. In 1989, the acquittal rate in federal criminal trials was $23 \% .1990$ SOURCEBOOK, supra note 1, at $502 \mathrm{tbl}$. 5.25. The rate of acquittal is slightly lower for felony defendants in state court. Id. at $526 \mathrm{tbl} .5 .51$.

4. The most influential (and prolific) critics are Albert Alschuler and Stephen Schulhofer, both professors at the University of Chicago. See Albert W. Alschuler, The Changing Plea Bargaining Debate, 69 CAL. L. REV. 652 (1981) [hereinafter Alschuler, Changing Debate]; Albert W. Alschuler, The Defense Attorney's Role in Plea Bargaining, 84 YALE L.J. 1179 (1975) [hereinafter Alschuler, Defense Attorney's Role]; Albert W. Alschuler, The Prosecutor's Role in Plea Bargaining, 36 U. CHI. L. REV. 50 (1968) [hereinafter Alschuler, Prosecutor's Role]; Albert W. Alschuler, The Trial Judge's Role in Plea Bargaining, 76 CoLUM. L. REv. 1059 (1976) [hereinafter Alschuler, Trial Judge's Role]; Stephen J. Schulhofer, Criminal Justice Discretion as a Regulatory System, 17 J. LEGAL STUD. 43 (1988) [hereinafter Schulhofer, Criminal Justice Discretion]; Stephen J. Schulhofer, Due Process of Sentencing, 128 U. PA. L. REv. 733 (1980) [hereinafter Schulhofer, Due Process]; Stephen J. Schulhofer, Is Plea Bargaining Inevitable?, 97 HARV. L. REv. 1037 (1984) [hereinafter Schulhofer, Plea Bargaining]. But while these two have led the academic charge (and to a considerable extent shaped the academic consensus), they are by no means alone. For a representative sample of the other scholarship, see MALCOLM M. FEELEY, THE PROCESS IS THE PUNISHMENT 
process, including (perhaps especially) the courts, seem remarkably untroubled by it. Not only is the practice widespread, but participants generally approve of it. Why is plea bargaining at once so widely condemned and so widely tolerated?

One place to look for an answer is in the law and literature of plea bargaining as contract. Plea bargains are, as the name suggests, bargains; it seems natural to argue that they should be regulated and evaluated accordingly. But while that argument is common, there is little agreement on where it leads. Two of the harshest and most influential critics of plea bargaining, Albert Alschuler and Stephen Schulhofer, maintain that contract theory supports prohibiting any bargained-for allocation of criminal punishment. ${ }^{6}$ The courts, on the other hand, have proceeded to construct a body of contract-based law to regulate the plea bargaining process, taking for granted the efficiency and decency of the process being regulated. The many academic arguments for abolishing (or at least severely restricting) plea bargaining have thus been largely ignored. It is tempting to explain this reaction as a product of the chasm between an overly fastidious academic world and the unpleasant realities of modern criminal processes. But the intuition that plea bargaining is fundamentally flawed is too strong and too widespread to be so casually dismissed.

There is a better explanation for the tension between courts and practitioners on the one hand, and theorists on the other: plea bargains are both paradigmatic bargains of the sort we routinely enforce in other contexts and the product of a seriously flawed bargaining structure. The critics, for their part, have misused or misapplied classical contract arguments for limiting contractual autonomy. Properly understood, classical contract theory supports the freedom to bargain over criminal punishment. At the same time, there are fundamental structural impediments in the plea bargaining context that may underlie the widespread antipathy to the practice. These barriers to efficient bargaining are not, however, grounds for abolition, but instead suggest more focused reforms of current practices.

(1979); Douglas G. Gifford, Meaningful Reform of Plea Bargaining: The Control of Prosecutorial Discretion, 1983 U. ILL. L. REV. 37; Kenneth Kipnis, Plea Bargaining: A Critic's Rejoinder, 13 LAW \& SOC'Y REV. 555 (1979); John H. Langbein, Torture and Plea Bargaining, 46 U. CH. L. REV. 3 (1978).

Opposition to plea bargaining is not limited to academics; much of the public (both in the United States and elsewhere) disapproves of the practice as well. See, e.g., Stanley A. Cohen \& Anthony N. Doob, Public Attitudes to Plea Bargaining, 32 CRIM. L.Q. 85, 93-100 (1989-90) (study finding that large majority of Canadians opposes plea bargaining). But there is a major differe $7 c e$ between popular and academic attitudes: while the academics tend to dislike plea bargaining because it treats defendants unfairly, the public tends to see the practice as treating defendants too leniently. See id. at 97.

5. The best evidence for this statement is the wonderful book by Milton Heumann, which surveys the process by which prosecutors, defense attorneys, and judges adapt to plea bargaining. See MuToN HEUMANN, PLEA BARGAINING (1978). According to Heumann, these actors typically begin with a strong distaste for the process, but as they become familiar with it, their view shifts to something between apathy and strong support.

6. Alschuler, Changing Debate, supra note 4, at 695-703; Schulhofer, Criminal Justice Discretion, supra note 4 , at $70-74$. 
In Part I of this Article, we use the perspective of classical contract theory to evaluate the case for prohibiting plea bargaining. This analysis shows that none of the standard arguments for limiting contractual autonomy hold in the plea bargaining context. Those standard arguments focus either on a defective bargaining process or on systematically unfair or distributionally unjust outcomes. But the contemporary plea bargaining process actually exceeds the process standards we apply to other sorts of bargaining, and the outcomes, while far from perfect, are also far removed from the kinds of problems that would ordinarily lead to a limitation of contractual autonomy.

In Part II, we use the techniques of modern decision analysis and bargaining theory to analyze the strategic interaction of parties to plea bargains. This approach suggests that the core objection to plea bargaining is not intrinsic to the relationship, but structural: strategic impediments to efficient bargains lead to a pooling of guilty and innocent defendants. The pooling phenomenon leads predictably to innocent defendants being offered (and taking) the same deals as guilty ones.

In Part III, we consider the implications of this analysis for legal doctrine. We argue that abolishing plea bargaining would not solve, and might even aggravate, the problem of failing to separate the innocent from the guilty. But abolition is not the only possibility-though it is the only one that has received sustained academic attention. Indeed, the single-minded academic focus on abolition may have contributed to a second-order problem: the development of legal doctrine that makes strategic bargaining problems worse rather than better. By altering the doctrine that governs such issues as when and how bargains are enforced, the consequences of defendants' mistakes, and how background prices (i.e., post-trial sentences) are set, the state can reduce the incentives for strategic bargaining and improve the efficiency and fairness of the plea bargaining process.

\section{Plea Bargaining as Classical Contract}

The criminal process that law students study and television shows celebrate is formal, elaborate, and expensive. It involves detailed examination of witnesses and physical evidence, tough adversarial argument from attorneys for the government and defense, and fair-minded decisionmaking from an impartial judge and jury. For the vast majority of cases in the real world, the criminal process includes none of these things. Trials occur only occasionally-in some jurisdictions, they amount to only one-fiftieth of total dispositions. ${ }^{7}$ Most cases are disposed of by means that seem scandalously casual: a quick conversation in a prosecutor's office or a courthouse hallway between attorneys familiar with only the basics of the case, with no witnesses present, leading to a proposed

7. See, e.g., FEELEY, supra note 4 , at 185 \& n.9. 
resolution that is then "sold" to both the defendant and the judge. ${ }^{8}$ To a large extent, this kind of horse trading determines who goes to jail and for how long. That is what plea bargaining is. It is not some adjunct to the criminal justice system; it is the criminal justice system.

The idea of allocating criminal punishment through what looks like a street bazaar has proved unappealing to most outside observers. Critics point to the seeming hypocrisy of using an elaborate trial process as window dressing, while doing all the real business of the system through the most unelaborate process imaginable. ${ }^{9}$ They emphasize the unfairness (and inaccuracy) of determining defendants' fate without full investigation, without testimony and evidence and impartial factfinding; they emphasize too how this unfairness disproportionately harms the poor and unsophisticated. ${ }^{10}$ Perhaps especially, they note the seeming pervasiveness of coercion and fraud in the system. Defendants accept bargains because of the threat of much harsher penalties after trial; they are thus forced to give up the protections that the trial system's many formalities provide. ${ }^{11}$ And judges often give bargained-for sentences because of what prosecutors and defense lawyers do not say at sentencing; the sentencing hearing seems rigged to support the deal that the two attorneys have already struck. $^{12}$

These criticisms often are rooted in the meaning and scope of various constitutional rights. We do not address such constitutional arguments here. But attacks on plea bargaining also have their origin in contract, in the norms that define the boundaries of acceptable exchange elsewhere in the legal system. passim.

8. The most vivid and richly textured descriptions of this process are in HeUMaNs, supra note 5 ,

9. E.g., DAVID A. JONES, CRME WITHOUT PUNISHMENT 111 (1979); Alschuler, Changing Debate, supra note 4, at 677-78; Graham Hughes, Pleas Without Bargains, 33 RUTGERs L. REV. 753 (1981); John Kaplan, American Merchandising and the Guilty Plea: Replacing the Bazaar with the Department Store, 5 AM. J. CRIM. L. 215, 218 (1977).

10. E.g., Alschuler, Defense Attorney's Role, supra note 4, at 1180; Kenneth Kipnis, Criminal Justice and the Negotiated Plea, 86 ETHICs 93, 105-06 (1976); Stephen J. Schulhofer, Effective Assistance on the Assembly Line, 14 N.Y.U. REV. L. \& SOC. CHANGE 137, 142, 144 (1986).

11. For two particularly pungent versions of this argument, see Kipnis, supra note 10, at 97-99 (analogizing a defendant's choice in plea bargaining to threat at gunpoint); Langbein, supro note 4 (analogizing plea bargaining to medieval torture). For a more measured version of the coercion criticism, see Conrad G. Brunk, The Problem of Voluntariness and Coercion in the Negotiated Plea, 13 LAW \& Soc'Y REV. 527 (1979).

12. See, e.g., Alschuler, Trial Judge's Role, supra note 4, at 1062-64; David A. Jones, Negotiation, Ratification and Rescission of the Guilty Plea Agreement: A Contractual Analysis and Typology, 17 DuQ. L. REV. 591, 604 (1978-79); Schulhofer, Due Process, supra note 4, at 745, 753. Heumann's book, though not so critical of the institution of plea bargaining, confirms that bargains are essentially about how to present the case to the judge, a notion that suggests a certain amount of deception and concealment. See HEUMANN, supra note 5, at 38-39, 43-46.

Note that this dynamic has been significantly altered in jurisdictions that have adopted mandatory sentencing guidelines. See infra notes 181-83 and accompanying text. Sentencing in such jurisdictions does not depend on the prosecutor's representations to the same extent as in discretionary sentencing systems because the guidelines often dictate a particular sentence. For purposes of our analysis, we assume a traditional regime (of the sort that many states still retain) in which the judge has a great deal of sentencing
discretion. 
Force, fraud, and even distributional unfairness are all grounds for restricting contract. If they are pervasive in the plea bargaining process, then plea bargaining should be abolished-not as a matter of constitutional law, but as a matter of contract law and contract principles.

That is the argument we wish to investigate. Our analysis proceeds in two stages. First, we consider whether the powerful norm of expanded choice-the norm that justifies a general presumption of enforceable bargains-also justifies enforcing plea bargains. Second, we examine whether any of the recognized limitations on bargaining autonomy argue for similar limitations in this context.

\section{A. The Norm of Expanded Choice}

Before marshaling arguments from contract that support limitations on contractual autonomy, we must first ask why plea bargains deserve a presumption of enforceability in the first place. The answer is simple: the freedom to exchange entitlements subsumes a freedom to contract for such an exchange. Either freedom is supported by norms of efficiency and autonomy. Parties who are denied either freedom to contract or freedom to exchange entitlements suffer unnecessary constraints on their choices, constraints that undermine the value of the entitlements themselves. This norm of expanded choice is so powerful in ordinary contracts that it justifies not only state subsidization of an enforcement mechanism, but also an array of default rules that delineate the terms of typical bargains, terms that define the contractual relationship unless the parties design their own alternatives. ${ }^{13}$

If the freedom to exchange entitlements were denied altogether in the allocation of criminal punishment, defendants would not have the option of pleading guilty in exchange for foregoing the burden and expense of a full trial. That is, not only plea bargains, but unbargained-for guilty pleas would be forbidden. Virtually no one argues that such a result would be socially desir-

13. For a more complete analysis of the foundations and limits of the expanded choice norm, see Charles J. Goetz \& Robert E. Scott, The Limits of Expanded Choice: An Analysis of the Interactions Between Express and Implied Contract Terms, 73 CAL. L. REV. 261 (1987). This normative principle has long been recognized in theoretical welfare economics. See Kelvin Lancaster, Welfare Propositions in Terms of Consistency and Expanded Choice, 68 ECON. J. 464 (1959).

The expanded choice norm has been the foundation for the developing theory of default rules in contract. See, e.g., Ian Ayres \& Robert Gertner, Filling Gaps in Incomplete Contracts: An Economic Theory of Default Rules, 99 YALE L.J. 87 (1989) [hereinafter Ayres \& Gertner, Filling Gaps]; Ian Ayres \& Robert Gertner, Strategic Contractual Inefficiency and the Optimal Choice of Legal Rules, 101 YALE L.J. 729 (1992) [hereinafter Ayres \& Gertner, Strategic Contractual Inefficiency]; Lucian A. Bebchuk \& Steven Shavell, Information and the Scope of Liability for Breach of Contract: The Rule of Hadley v. Baxendale, 7 J.L. ECON. \& ORGaNIZATION 284 (1991); Jules L. Coleman et al., A Bargaining Theory Approach to Default Provisions and Disclosure Rules in Contract Law, 12 HARV. J.L. \& PUB. POL'Y 639 (1989); Richard Craswell, Contract Law, Default Rules and the Philosophy of Promising, 88 MICH. L. REV. 489 (1989); Jason S. Johnston, Strategic Bargaining and the Economic Theory of Contract Default Rules, 100 YALE L.J. 615 (1990); Alan Schwartz, A Theory of Loan Priorities, 18 J. LEGAL STUD. 209 (1989); Robert E. Scott, A Relational Theory of Default Rules for Commercial Contracts, 19 J. LEGAL STUD. 597 (1990). 
able; the academic critics are not opposed to pleas, but only to plea bargains. ${ }^{14}$ But the line between granting defendants the option to plead guilty to forgo a trial and denying them the option to plead guilty to forgo the risk of a more severe punishment is far from clear. If the right to select a plea is an entitlement that can be traded for some purposes, why not for others? And if defendants may unilaterally exchange this entitlement for certain benefits under certain circumstances, then what justifies a prohibition on a party's freedom to contract for such an exchange?

The affirmative case for the enforceability of plea bargains is, then, fairly straightforward. The defendant has the right to plead not guilty and force the prosecutor to prove the case at trial. The prosecutor has the right to seek the maximum sentence for the maximum offense that can be proven. It is easy to imagine some circumstances where each party values the other's entitlement more than his own. ${ }^{15}$ If so, the conditions exist for an exchange that benefits both parties and harms neither. The defendant will trade the right to plead not guilty and force a trial for the prosecutor's right to seek the maximum sentence.

As with the typical executory contract, the parties to plea bargains do not actually trade the entitlements per se; instead they exchange the risks that future contingencies may materialize ex post that will lead one or the other to regret the ex ante bargain. ${ }^{16}$ Before contracting, the defendant bears the risk of conviction with the maximum sentence while the prosecutor bears the reciprocal risk of a costly trial followed by acquittal. An enforceable plea bargain reassigns these risks. Thereafter, the defendant bears the risk that a trial would have resulted in acquittal or a lighter sentence, while the prosecutor bears the risk that she could have obtained the maximum (or at least a greater) sentence if the case had gone to trial. Since it is difficult to know a priori which party enjoys the comparative advantage in risk reduction, a policy of contractual

14. There are exceptions, but the dominant view is that pleas are not objectionable in themselves. For example, both Alschuler and Schulhofer defend experiments that continue to permit large numbers of guilty pleas. Alschuler, Changing Debate, supra note 4, at 726-30 (defending Alaska's limitation on plea bargaining, but not pleas); Schulhofer, Plea Bargaining, supra note 4 (using as model Philadelphia system in which close to half of defendants pled guilty). And John Langbein, another leading critic of plea bargaining, extols the virtues of nonadversarial systems in which lawyers play only a small role (and in which pleas and confessions of some sort play a large role). See John H. Langbein, Land Without Plea Bargaining: How the Germans Do It, 78 MICH. L. REV. 204 (1979); cf. John H. Langbein, Understanding the Short History of Plea Bargaining, 13 LAW \& Soc'Y REV. 261 (1979) (arguing that plea bargaining had its origins in formalization of trial process coupled with ability of defendants to choose jury trials).

15. There are, in general, two quite different reasons why the parties might value each other's entitlement more: because of asymmetric adjudication costs and because of the different private information possessed by each party. See infra Part II.

16. The concept of a "regret contingency" is a key element in explaining the circumstances under which a promisor might fail to perform his promise. The "regret contingency" denotes the future occurrence of a condition that would motivate breach if breach were a costless option for the promisor. Such an occurrence implies that either the promisor or the promisee must bear a cost. See Charles J. Goetz \& Robert E. Scott, Enforcing Promises: An Examination of the Basis of Contract, 89 YALE L.J. 1261, 1273 (1980). 
autonomy is the only way that parties can reduce the social losses that result from uncertainty and frustrated expectations. ${ }^{17}$

Moreover, the gains the participants realize from the exchange presumably have social value, not just value to the bargaining parties. Plea bargaining provides a means by which prosecutors can obtain a larger net return from criminal convictions, holding resources constant. Criminal defendants, as a group, are able to reduce the risk of the imposition of maximum sanctions. Assuming that these social gains are not achieved at the expense of individual defendants, ${ }^{18}$ the system appears normatively acceptable in principle. In short, the existence of entitlements implies the right to exploit those entitlements fully, which in turn implies the right to trade the entitlement or any of its associated risks.

The argument that leads from the initial entitlement to contractual autonomy can be easily trumped, of course, by simply redefining the entitlement. Thus, for example, one might say that the right to trial is absolute or inalienable and therefore not subject to purchase or sale. Alternatively, defendants might be said to have not a right to trial, but rather a duty or obligation to force the government to prove the charges against them. ${ }^{19}$ (Prosecutors, by the same token, might have not the right to seek the maximum sentence, but the duty to do so. ${ }^{20}$ ) Under this conception, the entitlements are located elsewhere-with society or the larger community-and are not appropriate subjects for individual trades.

There are several responses to these rights-based attacks on bargaining. First, the nature of the right to trial argues strongly against a presumption of

17. Parties enter into contractual relationships in order to exploit the benefits of long-term planning and coordination. Even so, contingencies may subsequently materialize and frustrate parties' efforts to realize these shared objectives. Anticipating this, contracting parties must distribute the risks of their enterprise between themselves. Although there are a wide variety of risk-bearing options, all contracting parties have two dominant motivations. Initially, the parties wish to distribute risks in the least burdensome way. Thereafter, parties may seek to adjust their initial risk assignments in light of subsequent events. These risk distribution and adjustment objectives are highly interactive and frequently in conflict. The law's traditional deference to party autonomy thus seems to reflect the most sensible accommodation of the conflicting goals that characterize all contractual relationships. See Robert E. Scoth, Conflict and Cooperation in Long-Term Contracts, 75 CAL. L. REV. 2005, 2007, 2054 (1987).

18. Or, we should perhaps add, at the expense of the public: one might attack plea bargaining as a means by which prosecutors, with the collaboration of defense counsel, defraud the citizenry. The public reaction to the practice - criticizing the lenience that results-might suggest this, but we think it implausible. First, the alternatives to plea bargaining all require more expense per case, and the expense would be paid by the public. And while there are indeed serious agency cost problems that make prosecutors (sometimes) bad representatives of the public interest, those problems would still exist if plea bargaining were abolished; they would simply be transferred to the decision to charge. For these reasons, we discount the prosecutorial exploitation view.

19. See Alschuler, Changing Debate, supra note 4, at 678, $691-92$ (emphasizing the social benefits of going to trial).

20. Another way to frame this argument is to say that the socially correct sentences are the ones judges and juries give, not the ones that prosecutors negotiate. See id. at 680 . Schulhofer makes a different (and more sophisticated) version of this argument when he notes that prosecutors are imperfect representatives of social interests-in other words, that agency costs seriously infect the criminal justice process. Schulhofer, Criminal Justice Discretion, supra note 4, at 49-53. 
inalienability. There is a tendency to think about pleas as the alternative to the elaborate trial process that our system presently uses; those who draw the comparison between pleas and trials, perhaps unsurprisingly, tend to find the plea process wanting. But the nature of the criminal trial process is not an independent variable. If plea bargaining were abolished-if, that is, the system had to process many more cases by trial than it presently does-one might reasonably suppose that the trial process would be more casual than it is now. Any change in the structure of plea bargaining will necessarily have far-reaching feedback effects on the trial process itself. In sum, there is no preordained right to trial at stake in the plea bargaining debate. Rather, there is a choice between (1) a right (that may be bought and sold) to an elaborate trial, and (2) an inalienable right to a more casual trial process. ${ }^{21}$ For reasons we discuss below, we think defendants would prefer the former to the latter.

Of course, those who believe in truly inalienable rights might say that party preferences do not matter. Individual citizens have many rights that they might prefer to trade yet may not relinquish. Many people might find it welfare maximizing to sell their right to vote or their right to criticize particular government officials; sales of such entitlements are nevertheless forbidden. Perhaps the right of a criminal defendant to take his case to trial should be viewed in the same way.

This argument fails, however, because the right to trial differs in important ways from those rights that are ordinarily thought to be inalienable. When an individual sells his vote, the social costs of the transaction are borne by the rest of the electorate. The same principle applies to sales of the right to criticize government officials. There are obvious reasons not to permit sales of entitlements where the costs are imposed on third parties. Such is not the case with the right to trial; the defendant's entitlement is to a process of dispute resolution, and the parties to the bargain are the parties to the dispute. It follows that the parties do internalize the great majority of the costs and benefits of the bargain. ${ }^{22}$ Just as there is no inherent conflict between a tort plaintiff's right to a day in court and his ability to trade that right in settlement negotiations, there is no inherent conflict between the right to a criminal trial and the ability to sell that right for sentencing concessions.

The most plausible rights-based objection to plea bargaining is the claim that the right to trial simply does not belong to the defendant-and, by the same

21. That is why plea bargaining cannot fairly be seen as a straightforward unconstitutional conditions problem; the trial process is, in effect, a shifting target. Cf. Thomas R. McCoy \& Michael J. Mirra, Plea Bargaining as Due Process in Determining Guilt, 32 STAN. L. REV. 887, 904-10 (1980) (arguing that plea bargaining appears to fail under traditional unconstitutional conditions standards).

22. The parties do not internalize all the costs and benefits. For example, they do not internalize the symbolic value of trials-the value of the public spectacle of blame (or exoneration) and punishment. Nor do they capture the value of the new legal rules that are created through the litigation process. But these externalities are at least counterbalanced by the fact that the parties also do not bear the full cost of the trial process-the use of the court system, for example, is not chargeable to either the defense or the prosecution. 
token, that the government does not own the entitlement to prosecute for the highest possible charge. One who takes this position will naturally find plea bargaining objectionable. ${ }^{23}$ Except in unusual circumstances, parties do not and should not trade entitlements that belong to others with whom they have no agency relationship. This argument, however, seems inconsistent with many other features of contemporary criminal procedure. The entire structure of the criminal justice system presupposes that the relevant entitlements belong, in the meaningful sense of that term, to the defendant and prosecutor. Defendants are permitted to plead guilty if they wish, ${ }^{24}$ wholly apart from plea bargains; they are similarly permitted to confess to the police (which can be almost the same thing as pleading guilty) on their own initiative. Prosecutors are allowed to decide whom to prosecute, and for what. If our system were based on the notion that the relevant entitlements are externalized, these bedrock rules would have to be altered. This form of attack on plea bargaining, in other words, is really an attack on much else.

Even in rights terms, then, it seems plausible to begin with the presumption of enforceability, the presumption that flows logically out of the norm of expanded choice. (And that, of course, is the position that the system has taken as a matter of positive law: the relevant rights have long been held compatible with the practice of plea bargaining. ${ }^{25}$ ) The interesting question is whether the presumption can be overcome on the ground that the process and/or the product of plea bargaining is peculiarly defective-that bargains are either reached in a way that undermines their utility or renders them unfair, or that the bargaining outcomes are either unjust or socially harmful. These are precisely the kinds of defects that, under classical contract principles, would override a presumption of enforcement.

23. One can, however, see a guilty defendant as "owning" his entitlement primarily for the sake of others and still approve of plea bargaining. One of us has previously argued that many criminal procedure entitlements should be seen this way: defendants possess and can trade the entitlements, but they possess them primarily for the sake of others (e.g., the guilty for the innocent). See William J. Stuntz, Waiving Rights in Criminal Procedure, 75 VA. L. REV. 761 (1989). But even if one sees the right to trial this way-that is, if guilty defendants possess the entitlement solely for the sake of innocents-guilty people must be treated as if the right is wholly theirs because it is not possible to differentiate between them and innocent defendants. Id. at 795-801. In contexts where differentiation is feasible, the analysis changes-that is why, for example, deception and dishonesty in police interrogation are normatively acceptable, while similar tactics in plea bargaining are not. Id. at 829-34.

24. Defendants do not technically have the right to plead guilty; the judge may refuse, under some circumstances, to accept the defendant's plea. See North Carolina v. Alford, 400 U.S. 25, $38 \mathrm{nn} .10-11$ (1970). In the vast majority of cases, however, the decision whether to plead guilty is entirely the defendant's.

25. Santobello v. New York, 404 U.S. 257 (1971); Brady v. United States, 397 U.S. 742 (1970). A contracts perspective not only helps explain this doctrinal conclusion, it arguably provides the reason for that conclusion. See McCoy \& Mirra, supra note 21, at 910 (concluding that decisions rejecting constitutional challenges to plea bargaining "seem[] attributable to an assumption that plea bargaining is merely a contractual arrangement between a defendant and the state"). 


\section{B. The Contractual Case Against Plea Bargaining}

While classical contract theory supports a presumption favoring the enforcement of plea bargains, it also is the source of many arguments for prohibiting plea bargains, or at least substantially restricting them. A decade ago, in one of a series of famous articles attacking plea bargaining, Albert Alschuler argued that the practice is contractually deficient in a host of ways: many of the bargains are unconscionable; defendants accept prosecutors' offers under duress; the poor and ignorant suffer disproportionately; the bargains are the product of irrationality and mistake. ${ }^{26}$ These arguments amount to the basic objections to plea bargaining stated in contract form.

It might seem strange to look to contract theory to find reasons for prohibiting contracts that allocate criminal punishment, but contract law routinely embraces arguments for limiting itself. ${ }^{27}$ Those arguments (and Alschuler's contract-based criticisms) are of two general types. One class focuses on defects in the bargaining process. The normative claim that supports enforcing bargains is that voluntary exchange offers people more choices than they would otherwise enjoy and, other things being equal, more choice is better than less. Accepting for the moment the appeal of the expanded choice norm, the challenge for contract theory is how to preserve ils key elements: a free, informed, and rational choice. Preserving the core of this idea requires rules that prohibit enforcement where individual promises were the product of duress or unconscionable information deficits, or where the parties lacked the capacity and judgment to evaluate the risks being exchanged. ${ }^{28}$

A second class of objections focuses more directly on the outcome of certain bargains. The idea here is that the bargains themselves are faulty, regardless of whether the bargaining process was rational. Thus, for example, contracts of enslavement are unenforceable, and some bargains are not enforced because of socially harmful distributional consequences.

In the following sections, we consider both types of arguments and explore the various contract analogies just mentioned. In each instance, our goal is to identify the principle that justifies nonenforcement in contract law and to ask whether that principle justifies the categorical prohibition of plea bargains.

26. Alschuler, Changing Debate, supra note 4.

27. See, e.g., Duncan M. Kennedy, Form and Substance in Private Law Adjudication, 89 HARV. L. REV. 1685 (1976); Anthony T. Kronman, Paternalism and the Law of Contract, 92 YALE L.J. 763 (1983).

28. See ROBERT E. SCOTT \& DOUGLAS L. LESLIE, CONIRACT LAW AND THEORY 469 (1988). 


\section{Process-Based Justifications for Prohibiting Plea Bargaining}

All of the classical grounds for limiting contractual autonomy have been marshaled in the contemporary academic debate over plea bargaining. ${ }^{29}$ At the outset it is important to note that these various arguments have all been used to support the claim that plea bargaining is socially and morally harmful and should be prohibited. The contract arguments that focus on bad consequences are conceptually appropriate for such a claim, but the contract arguments that center on defective processes are ill-suited for a global critique. Doctrines such as fraud, unconscionability, and duress assume a regime in which enforcement is the norm. These doctrines only selectively deny enforceability. Nevertheless, one can overcome this conceptual hurdle by asking, as we do here, whether the plea bargaining context is so burdened by process defects as to justify a prophylactic rule prohibiting bargaining altogether.

\section{a. Duress}

One of the central arguments for prohibiting plea bargaining is the claim that such bargains are impermissibly infected by duress. ${ }^{30}$ Under ordinary contract principles, a duress defense is successful if the defending party can prove that he would not have entered into the contract absent the improperly coercive behavior of the other contracting party. ${ }^{31}$ At first glance, the defense seems entirely unproblematic. After all, facilitating the exercise of voluntary choice is the central normative justification for contractual enforcement. Not all coercion justifies nonenforcement, however. A poor consumer, for example, cannot avoid a contractual obligation on the sole ground that his impoverished circumstances forced him to accept an otherwise "voluntary" agreement. ${ }^{32}$ The duress claim must be based on the acts or conduct of the promisee and not merely on the necessities of the promisor. The wrongful acts that constitute duress may be either physical force or an improper threat, but in any case the compulsion must be "produced" by the promisee and not by exigent circumstances confronting the promisor. ${ }^{33}$

29. In addition to sources cited supra note 6, see Brunk, supra note 11; Gifford, supra note 4, at 55-61; Daniel F. Kaplan, Where Promises End: Prosecutorial Adherence to Sentence Recommendation Commitments in Plea Bargains, 52 U. CHI. L. REV. 751, 753-59 (1985); Kipnis, supra note 4, at 561-64.

30. See, e.g., Alschuler, Changing Debate, supra note 4, at 695-703; Brunk, supra note 11, at 542-52; Gifford, supra note 4, at 55; Jones, supra note 12, at 624-25; Kipnis, supra note 10, at 105-06; Langbein, supra note 4.

31. See, e.g., RESTATEMENT (SECOND) OF CONTRACTS § 175 (1988); 1 E. ALLAN FARNSWORTH, CONIRACTS 430-33 (2d ed. 1990); SCOTT \& LESLIE, supra note 28 , at 395-411.

32. SCOTT \& LESLIE, supra note 28 , at 395.

33. E.g., Chouinard v. Chouinard, 568 F.2d. 430, 434 (5th Cir. 1978) ("A duress claim . . . must be based on the acts or conduct of the opposite party and not merely on the necessities of the purported victim. Thus, the mere fact that a person enters into a contract as a result of pressure of business circumstances, financial embarrassment or economic necessity is not sufficient."). 
The archetypal contracts example of nonactionable "economic duress" is the lone gas station in the middle of the desert that charges a hundred dollars for a gallon of gas. The gas station may well get its asking price, because the difference between that price and the cost of going without is so high. But contract law has resolutely rejected the buyer's duress argument in such cases, on the sensible ground that the seller's actions did not produce the constraint on the buyer's choices (an empty gas tank in the desert), so the buyer was surely better off with the offer than without it. ${ }^{34}$ Put another way, the norm of expanded choice is solely concerned with the marginal effects of the contract on an individual's choices. A person with few and unpalatable choices may live in a coercive environment. An offer that exploits those circumstances is nevertheless value enhancing, and enforcement is appropriate. More choices are better, even-perhaps especially - if one has few to begin with.

How does duress, thus conceived, apply in the plea bargaining context? The duress argument against plea bargaining is that the large differential between post-trial and post-plea sentences creates a coercive environment in which the criminal defendant has no real alternative but to plead guilty. No plea produced by that sort of pressure could be deemed voluntary. ${ }^{35}$

There are several responses to this claim. First, the argument about the size of the sentencing differential reduces to the claim that the choice to plead guilty is too generous to the defendant, an odd claim to make alongside the general claim that the system treats the defendant unfairly. ${ }^{36}$ To be sure, the plea favors the defendant only because the post-trial sentence is so high. But this is a complaint about background sentences, not plea bargaining. The problem of background sentences only implicates plea bargaining (as distinct from sentencing policy) to the extent that it suggests strategic manipulation by prosecutors. As we argue below, there is a serious problem with strategic incentives in plea bargaining, but it would be better solved by specific rules for combating the prosecutor's strategic behavior than by abolishing plea bargaining. ${ }^{37}$

Moreover, the argument misunderstands the doctrine of economic duress. As the preceding discussion suggests, coercion in the sense of few and unpalatable choices does not necessarily negate voluntary choice. So long as the posttrial sentences have not been manipulated by the prosecutor, the coercive elements of the plea bargaining environment do not corrupt the voluntariness

34. See, e.g., Chouinard, 568 F.2d 430; Business Incentives Co. v. Sony Corp. of Am., 397 F. Supp. 63, 69 (S.D.N.Y. 1975); Standard Box Co. v. Mutual Biscuit Co., 103 P. 938 (Cal. App. 1909); Cheshire Oil Co. v. Springfield Realty Corp., 385 A.2d 835 (N.H. 1978); Metro-Goldwyn Mayer Distrib. Corp. v. Cooke, 56 S.W.2d 489 (Tex. Civ. App. 1933).

35. See, e.g., sources cited supra note 30 .

36. For a discussion emphasizing this point, see Frank Easterbrook, Criminal Procedure as a Market System, 12 J. LEGAL STUD. 289, 311-16 (1983). Alschuler responds by acknowledging the argument, and then simply denying that there is any inconsistency. See Alschuler, Changing Debate, supra note 4, at 65960.

37. See infra text accompanying notes 167-83. 
of the plea agreement. ${ }^{38} \mathrm{~A}$ large sentencing differential does not imply coercion a priori. Rather, it is entirely consistent with the assumption that the right to take the case to trial is a valuable entitlement. The prosecutor gains something very valuable when she avoids trial. It is hardly surprising that she will pay handsomely for it.

\section{b. Unconscionability}

The fact that classical duress does not infect the majority of plea bargains does not completely answer the coercion claim. The doctrine of unconscionability provides an alternative argument for nonenforceability. That doctrine serves as a kind of backstop, a means of granting relief where defects in the bargaining process, though serious, do not rise to the level of fraud or duress. ${ }^{39}$ As a general proposition, the doctrine of unconscionability "explains and justifies the limits that should be placed upon the bargain principle on the basis of the quality of the bargain." ${ }^{40}$ Commentators generally agree that this inquiry into the quality of the bargain has both a substantive and a non-substantive or procedural dimension. Substantive unconscionability usually refers to the terms of the agreement itself, such as an "'unreasonable' price or contract term which deprives a party of the "essence of his bargain." ty, on the other hand, refers to practices that impermissibly limit a party's ability to make rational choices about whether to accept the bargain or about its terms. ${ }^{42}$

The substantive branch of unconscionability has little relevance for plea bargaining. Typically, a plea bargain involves a simple promissory exchange: the defendant trades his promise to plead guilty (and waives his right to trial) for the prosecutor's promise to recommend a specific sentence. There are no collateral terms that severely disadvantage the defendant or deprive him of the essence of what was bargained for. Indeed, the fact that the state delivers the essence of what was bargained for-a significant sentencing differential-is what critics of plea bargaining find so troubling. Thus, claims that plea bargains are generally unconscionable must rest on nonsubstantive or procedural grounds.

In contract law, there are two such grounds: information deficits and market unresponsiveness. ${ }^{43}$ The paradigmatic case of unconscionable information

38. For the same point expressed in somewhat different terminology, see ALAN WERTHEMER, COERCION 122-43 (1987) (arguing that duress requires both psychological coercion and wrongful threat, and that only the former is present in plea bargaining).

39. SCOTT \& LESLIE, supra note 28, at 455; see also Richard A. Epstein, Unconscionability: A Critical Reappraisal, 18 J.L. \& ECON. 293 (1975).

40. Melvin A. Eisenberg, The Bargain Principle and its Limits, 95 HARV. L. REV. 741, 799 (1982).

41. SCOTT \& LESLIE, supra note 28 , at 69.

42. Id. In general, procedural unconscionability describes a defective bargaining process-an unreasonable failure of one party to inform the other about important aspects of the exchange.

43. Alan Schwartz identifies two other grounds for nonsubstantive unconscionability: poverty and incompetence. Alan Schwartz, A Reexamination of Nonsubstantive Unconscionability, 63 VA. L. REV. 1053, 
deficits is the fine print boilerplate clause buried in a standard form agreement that purports to reassign risks in uncustomary ways. ${ }^{44}$ As with duress, it is not enough for the promisor to show that he was uninformed; rather, the information deficit must have been, in some sense, produced by the defendant. ${ }^{45}$ Thus, this most common claim of unconscionability is really a claim of fraudulent concealment.

The information-based argument seems largely inapplicable to the standard plea bargain. Plea bargains are not standard form adhesion contracts filled with hard-to-understand terms and conditions. On the contrary, the typical plea bargain is strikingly similar to the simple dickered bargain--my car for $\$ 500$ that is the staple example of enforceable exchange in contract law. Moreover, the criminal defendant, unlike the consumer surprised by fine print disclaimers, has legal counsel. The fact that plea bargaining takes place between lawyers substantially mitigates any concern with the concealment of relevant information. This is true even in a world in which defendants receive substandard lawyers (at substandard pay). ${ }^{46}$ Once again, the terms of plea bargains are not usually complex, so sophisticated analysis is not called for, and its absence is not usually much of a problem. Moreover, low-quality legal representation would be more problematic, not less, in a world without plea bargaining, since the same substandard lawyers would have greater opportunity for error when conducting criminal trials than when negotiating pleas. ${ }^{47}$

Nor is there anything unconscionable about a slapdash bargaining process. It is true that bargains are often reached after only a short conversation between the prosecutor and defense counsel. ${ }^{48}$ But it does not follow that such bargains are ill-considered or that defendants (or their lawyers) are inadequately informed. Both bargaining agents are typically repeat players who deal with each

1054 (1977). In fact, courts rarely declare a contract or a term to be unconscionable simply because a party to the agreement is poor or cognitively impaired. In any case, these classes of objections properly fall within our discussion of patemalistic grounds for nonenforcement. See infra text accompanying notes 60-76.

44. The classic example is Henningsen v. Bloomfield Motors, Inc., 161 A.2d 69 (N.J. 1960). Though the decision in this famous case cut much more broadly than necessary-Prosser celebrated it as heralding the end of the privity requirement in products cases, William L. Prosser, The Fall of the Citadel (Strict Liability to the Consumer), 50 MIN. L. REv. 791, 791-93 (1966)-the facts strongly suggest something akin to fraudulent concealment: the clause limiting warranty protection was buried in fine print on the back of the contract.

45. In other words, unconscionability is not a device for transforming ordinary mistakes into excuses for nonperformance. See, e.g., Merit Music Serv. v. Sonneborn, 225 A.2d 470 (Md. 1967).

46. For attacks on plea bargaining based on the poor quality of most appointed defense counsel, see Colloquium, Effective Assistance of Counsel for the Indigent Criminal Defendant: Has the Promise Been Fulfilled?, 14 N.Y.U. REV. L. \& Soc. CHANGE 1 (1986).

47. Even low-quality legal representation provides huge protection against the kind of fraudulent conduct that makes for genuine unconscionability. The real problem with low-quality defense counsel is not that prosecutors slip hidden contract terms past them, but that they do a poor job of negotiating the basic contract term-the recommended sentence. For a discussion of what to do about that problem, see infra text accompanying notes 160-66.

48. See HEUMANN, supra note 5, at 35; Schulhofer, supra note 10 , at 144. 
other and with the system regularly. ${ }^{49}$ This means that the bargaining range is likely to be both small and familiar to the parties, as both prosecutors and defense attorneys have a great deal of information about customary practices. ${ }^{50}$ Each side, in other words, is likely to have a good sense of the "market price" for any particular case. ${ }^{51}$

The second prong of procedural unconscionability rests on the notion of market unresponsiveness or disparate bargaining power. A product seller or secured creditor, especially one with market power, ${ }^{52}$ is believed to have a great deal of leverage over an individual buyer or debtor. Bargaining power alone has rarely been sufficient ground for nonenforcement of ordinary contracts. ${ }^{53}$ Courts have, however, identified a class of contract cases in which the bargaining power problem can be severe enough to warrant nonenforcement: standard form, adhesion contracts, with the powerful party forcing the less powerful counterpart to "take it or leave it." "54

Even assuming the basic soundness of the bargaining power argument, ${ }^{55}$ it does not apply to many plea bargains. Plea bargains are often individually dickered, with terms that are altered by both sides through individualized negotiations. ${ }^{56}$ And there is a telling reason why this is so-why, that is, plea

49. This is a familiar point that is appropriately emphasized throughout Heumann's account of the process. HEUMANN, supra note 5.

50. That is, neither side is likely to make large errors in estimation given their familiarity with each other, similar cases, and the court system.

51. See HEUMANN, supra note 5, at 38-39, 42-43, 120. This is likely to be true whether defense counsel is privately hired or works for a public defender's office. See Thomas M. Uhlman \& N. Darlene Walker, A Plea Is No Bargain: The Impact of Case Disposition on Sentencing, 60 SOC. ScI. Q. 218, 231 (1979) (finding no difference in case dispositions between public defenders and private counsel).

52. Of course, where substitutes are readily available, the meaning of bargaining power becomes unclear, and perhaps unimportant. That is why the famous argument in Friedrich Kessler, Contracts of Adhesion-Some Thoughts about Freedom of Contract, 43 CoLUM. L. REV. 629 (1943)-that whenever large businesses offer individuals standard form agreements there is a vast disparity in bargaining power-is wrong. See, e.g., SCOTT \& LESLIE, supra note 28, at 67-68; George L. Priest, A Theory of the Consumer Product Warranty, 90 YALE L.J. 1297 (1981); Alan Schwartz \& Louis L. Wilde, Imperfect Information in Markets for Contract Terms: The Examples of Warranties and Security Interests, 69 VA. L. REV. 1387 (1983).

53. See, e.g., U.C.C. $\$ 2-302 \mathrm{cmt}$. 1 (1989) ("The principle is one of the prevention of oppression and unfair surprise ... and not of disturbance of allocation of risks because of superior bargaining power."); see also Frame v. Merrill Lynch, Pierce, Fenner \& Smith, Inc., 97 Cal. Rptr. 811 (1971) (while bargaining strength was unequal, enforcement of an arbitration clause did not result in unfair imposition); Wille v. Southwestern Bell Tel. Co., 549 P.2d 903 (Kan. 1976) (disparity of bargaining power alone is insufficient); RESTATEMENT (SECOND) OF CONTRACTS $\& 179$ (1988).

54. Note that it is the combination of standard-form contracting and market power that creates the problem; standard forms alone are not enough. See supra note 52. For representative cases, see Wheeler v. St. Joseph Hosp., $133 \mathrm{Cal}$. Rptr. 775 (1976) (superior bargaining position coupled with contract of adhesion); Weidman v. Tomaselli, 365 N.Y.S.2d 681 (County Ct.) (same), aff'd, 386 N.Y.S.2d 276 (App. Term 1975); Seabrook v. Commuter Hous. Co., 338 N.Y.S.2d 67 (Civ. Ct. 1972) (long and complex lease printed in small type and containing many highly technical terms).

55. Professors Schwartz and Wilde have argued that even given market power, firms will not extract monopoly rents in the form of one-sided contract terms, but will instead raise prices. See Schwartz \& Wilde, supra note 52 . And in the plea bargaining context, prices are monitored by judicial sentencing decisions.

56. The key aspect of successful bargaining for defense attomeys is developing a sense of what a case is "worth." Without such a sense, the attomey will tend to accept unfavorable prosecutorial offers; with it, he will dicker successfully for a better deal. See HEUMANN, supra note 5, at 75-78. But cf. Jones, supra 
bargaining has so little in common with the contexts that give rise to paradigmatic adhesion contracts. An individual customer for a mass-marketed good or service can impose only a small cost on the seller, so that while the seller may have something very important to offer an individual buyer, that same buyer does not have something very important to offer the seller. (To put it differently, the gains from trade in transactions with an idiosyncratic buyer are dwarfed by the costs of crafting a nonstandard, individually dickered contract. ${ }^{57}$ ) The pressures that motivate the behavior of the seller of mass-marketed goods stem from the market as a whole, not from the need to reach a bargain with any particular customer. It is this unresponsiveness to individual, idiosyncratic preferences that underlies standard form, "take it or leave it" contracts. ${ }^{58}$

Plea bargaining is strikingly different. Sentence reductions are not massmarketed precisely because the individual defendant has, in effect, a call on the prosecutor's time. Each defendant can call on the prosecutor to try the case, forcing her to use time and effort that would otherwise be spent processing other cases. For the prosecutor, the opportunity cost of a failure to purchase this call from any individual defendant substantially exceeds the transaction costs of negotiating an individualized contract. The defendant's entitlement thus motivates prosecutors to bargain - not simply to make offers and walk away. To be sure, the bargaining dynamic in plea negotiations does not compel the prosecutor to compromise or to offer any particular defendant a different deal from those offered to others charged with similar offenses; signaling problems may limit the prosecutor's flexibility. And as we suggest below, strategic considerations may well limit the efficiency of the bargaining process in particular cases. ${ }^{59}$ Nevertheless, while it may not be in the prosecutor's interests to offer different deals to different defendants, it is in her interests to bargain for a deal with each defendant. It is the absence of such individualized bargaining in other settings that supports claims of unconscionability on the basis of unequal bargaining power.

note 12 , at $628-29$ (noting that while some terms, including price, are individually negotiated, other terms of bargain, such as defendant's waiver of certain legal claims, are treated as nonnegotiable).

57. See Schwartz, supra note 43 , at 1064-65.

58. Standard form contracts harm buyers as a whole only when they contain clauses that many buyers do not want and would pay to avoid. Assuming that buyers are informed and competent, such disfavored clauses will not exist: sellers would compete for the business of buyers by offering the preferred contract clauses. Standard form contracts, therefore, can only disadvantage buyers with idiosyncratic tastes in contract clauses who cannot purchase the terms that they want. Of course, such buyers cannot purchase other product attributes (such as 12-cylinder automobiles) that are generally disdained or otherwise unpopular. See ALAN SCHWARTZ \& ROBERT E. SCOTT, SALES LAW AND THE CONTRACTING PROCESS 184-85 (2d ed. 1991).

59. See infra Part II. 


\section{c. Incompetency and Poor Judgment (Herein of Paternalism)}

The preceding discussion suggests that the laundry list of complaints raised by critics of the plea bargaining process is a symptom of a larger and more fundamental claim: that plea bargaining is simply "unfair" to defendants. Even if their decisionmaking is informed, and even if bargains are not the product of fraud or duress, defendants are victimized because they are in general unable to assess their "true" interests when they bargain with the government. In other words, abolishing plea bargaining may be justifiable on paternalist grounds.

Legal regulation is often motivated by paternalism, although these motivations are rarely acknowledged. Duncan Kennedy aptly defines paternalism as the overruling of the preferences of an affected group. ${ }^{60}$ The key to the definition, the point that separates paternalist arguments from distributive or allocative ones, is that the supposed beneficiaries do not agree that they are better off and, in fact, would prefer to return to the prior regime were they free to do so. ${ }^{61}$ Obvious examples of this sort of regulation include the nonenforceability of contracts made by infants and incompetents. ${ }^{62}$ In such cases, the essence of the paternalist claim - and the source of the prohibition of contracting - is the assumption of either a cognitive impairment, a volitional impairment, or both. If the same assumptions can fairly be made in plea bargaining, there is a strong paternalist argument for aggressive legal regulation, or even outright prohibition.

\section{(i) Cognitive biases}

If plea negotiations are peculiarly susceptible to systematic errors of judgment, then the bargaining process can no longer be trusted to generate an efficient result. Consider in this connection the now-familiar anchoring phenomenon, which suggests that the way choices are framed affects individuals' assessments of the gains and losses of exercising any particular option. ${ }^{63}$

60. Duncan Kennedy, Distributive and Paternalist Motives in Contract and Tort Law, with Special Reference to Compulsory Terms and Unequal Bargaining Power, 41 MD. L. REv. 563, 624-29 (1982).

61. See Robert E. Scott, Rethinking the Regulation of Coercive Creditor Remedies, 89 COLUM. L. REV. 730, 776 (1989).

62. Id. at 778. In the case of infants and incompetents, nonenforceability rests on an assumption of immature judgment. See, e.g., Williamson v. Matthews, 379 So. 2d. 1245, 1247-48 (Ala. 1980) (incompetence includes inability to reason and exercise judgment); Kiefer v. Fred Howe Motors, Inc., 158 N.W.2d 288, 290 (Wis. 1968) (arguing that minor is immature in both mind and experience and should therefore be protected from his bad judgments).

63. For the initial discussion of this phenomenon, see Amos Tversky \& Daniel Kahneman, Judgment Under Uncertainty: Heuristics and Biases, 185 SCIENCE 1124, 1128-30 (1974) [hereinafter Tversky \& Kahneman, Judgment Under Uncertainty]. The authors develop the point more fully in Daniel Kahneman \& Amos Tversky, Choices, Values, and Frames, 39 AM. PsYCHOLOGIST 341 (1984), and in Amos Tversky \& Daniel Kahneman, The Framing of Decisions and the Psychology of Choice, 211 SCIENCE 453 (1981). One of us has previously discussed the relevance of this literature for legal policymaking. See Robert E. Scott, Error and Rationality in Individual Decisionmaking: An Essay on the Relationship Between Cognitive Illusions and the Management of Choices, 59 S. CAL. L. REv. 329, 338-42 (1986). 
Criminal defendants may suffer from this type of cognitive error if the benefits from refusing a proposed plea bargain are anchored to the prospect of acquittal-a prospect that may seem remote when the bargain is struck. Anchoring the benefits of trial to the remote possibility of acquittal may irredeemably impair the ability of criminal defendants to evaluate the choice correctly. And the error will not be random. According to some studies, individuals tend both to overestimate the likelihood of conjunctive events, such as events leading to conviction, and to underestimate the likelihood of disjunctive events, such as acquittal after trial. ${ }^{64}$ As a result, defendants may not be fully compensated for their guilty pleas, in which case they presumably would prefer a world without plea bargaining.

There are three responses to this argument. First, the anchoring phenomenon, like other familiar decisionmaking biases incorporated into the legal literature, is the subject of serious dispute among psychologists. ${ }^{65}$ It would make little sense to base wide-ranging legal policy judgments on psychological research that is questionable within its own discipline. Second, decisionmaking biases are traditionally used to explain seemingly irrational behavior-conduct that appears to cut against self-interest in some important way. Thus, for example, some scholars have argued that cognitive biases should influence the legal treatment of product safety risks, because consumers appear to underestimate those risks in their purchasing decisions. ${ }^{66}$ But in the plea bargaining context, there is no superficial irrationality to explain. Defendants plead guilty in return for important sentencing concessions. Prosecutors make concessions in return for substantial savings in time and energy and the elimination of the risk of acquittal. The bargain appears entirely rational. If the law assumes cognitive error despite apparently rational behavior by contracting parties (represented by lawyers no less), the legitimacy of all contracts is called into question. The cognitive bias argument against plea bargaining thus proves too much.

Finally, even if the biasing effects of framing are important, there are other means of correcting for them that do not involve prohibition. Enhanced disclosure and cooling-off periods are the obvious (and familiar) examples from the law of consumer transactions. ${ }^{67}$ Indeed, plea bargaining doctrine already uses

64. Tversky \& Kahneman, Judgment Under Uncertainty, supra note 63, at 1128-30. Interestingly enough, some have argued that innocent defendants overestimate the likelihood of acquittal at trial. McCoy \& Mirra, supra note 21, at 924.

65. See Gerd Gigerenzer, How to Make Cognitive Illusions Disappear: Beyond "Heuristics and Biases," 2 EUR. REV. SOC. PSYCHOL. 83 (1991) (arguing that most decisionmaking "biases" stem from errors by testers in presentation of statistical choices). In addition to Gigerenzer's critique, there is both theoretical and empirical support for the proposition that much seemingly irrational decisionmaking stems from the adoption of rational precommitment or self-monitoring strategies. See sources cited in Scoth, supra note 61, at 769-70 $\mathrm{nn} .127-29$.

66. See Daniel A. Farber, Contract Law and Modern Economic Theory, 78 Nw. U. L. REv. 303, 331-33 (1983); Note, Enforcing Waivers in Products Liability, 69 VA. L. REV. 1111, 1127-36 (1983).

67. See, e.g., RESTATEMENT (SECOND) OF TORTS $\$ 402 \mathrm{~A} \mathrm{cmt.j} \mathrm{(1965)} \mathrm{(discussing} \mathrm{seller's} \mathrm{duty} \mathrm{to} \mathrm{wam}$ of product dangers); FTC Cooling-Off Period for Door-to-Door Sales Rule, 16 C.F.R. $§ 429.1$ (1991). 
these devices to some extent. Judges are typically required to engage defendants in detailed "plea colloquies" in order to ensure that defendants understand what they are getting and what they are giving up. ${ }^{68}$ And as a general matter, defendants are permitted to rescind bargains up to the time they enter their pleas, as long as they have not induced substantial detrimental reliance by the government. ${ }^{69}$ Most importantly, of course, defendants are given lawyers. ${ }^{70}$ These rules should perhaps be modified or extended, but the point remains: cognitive biases are not only speculative, but also remediable by measures that fall far short of abolition.

\section{(ii) Poor judgment}

The possibility of cognitive error does not explain prohibitions against contracting with infants or incompetents; ${ }^{71}$ nor does it justify the nonwaivability of bankruptcy discharge. ${ }^{72}$ These restrictions are motivated instead by the idea of human fallibility or poor judgment. The claim is simple: people sometimes need to be protected from themselves. Certain groups-not only infants and incompetents, but the poor, uneducated, or unsophisticated as well-may, in certain settings, lack the capacity to make the choices that, by some established criterion, they ought to prefer. Infants, for example, are inclined to recklessness and impulsiveness because, in Kronman's terms, they lack "moral imagination." T3 This characteristic explains why contract law has long prevented them from making binding commitments.

When applied to criminal defendants in the plea bargaining setting, this type of argument has two problems. First, consider the implications of the idea that poor and unsophisticated criminal defendants (which surely describes a large portion of those who enter bargained-for guilty pleas) are inclined to reckless contracting behavior. This proposition predicts that such defendants will refuse to accept good deals and will instead insist on trials. This disadvantages them, so the argument goes, because post-trial sentences are longer in a

68. See FED R. CRMM. P. 11(c); 5 WEST'S FEDERAL FORMS $\S 7281$ (1971) (form for standard plea colloquy). For representative state rules mandating plea colloquies, see 17 ARIZ. REV. STAT. ANN. $\$ 17.2$ (1987); ILL. ANN. STAT. ch. 110A, para. 402 (Smith-Hurd 1985).

69. See Jones, supra note 12 , at $597-98,607-09$. The same rule applies to prosecutors. See Mabry v. Johnson, 467 U.S. 504 (1984).

70. For evidence that lawyers help render plea decisions more rational and less dominated by emotion, see Jerald W. Cloyd, Prosecution's Power, Procedural Rights, and Pleading Guilty: The Problem of Coercion in Plea Bargaining Drug Cases, 26 SOC. PROBS. 452, 455, 461-65 (1979). On the importance of all of these legal rules as information-transfer (and hence rationality-enhancing) devices, see Richard $P$. Adelstein, The Negotiated Guilty Plea: A Framework for Analysis, 53 N.Y.U. L. REV. 783, 810-14 (1978).

71. See supra note 62.

72. Thomas Jackson has developed a normative justification for the prohibition on discharge waivers based on a theory of overcommitment or aberrant judgment. See Thomas H. Jackson, The Fresh-Start Policy in Bankruptcy Law, 98 HARV. L. REV. 1393, 1404-24 (1985).

73. Kronman, supra note 27, at 795-96; see also Elizabeth S. Scott, Judgment and Reasoning in Adolescent Decisionmaking, 37 VILL. L. REV. (forthcoming 1992) (arguing that problem with juvenile decisionmaking is not lack of cognitive ability, but absence of mature judgment). 
world with plea bargaining than in a world without it. But the evidence (and much of the criticism) is that defendants usually take the pleas rather than risk the trials. The vast proportion of guilty pleas, over ninety percent in some jurisdictions, ${ }^{74}$ suggests that most defendants, including those who are poor and unsophisticated, prefer the certain, lower sentence to the post-trial alternative. ${ }^{75}$ To be sure, some defendants accept bad deals. But disallowing plea bargaining in order to prevent that type of error imposes the risk of a much longer sentence on all defendants in order to protect against the misjudgments of a few. It is not clear that even the objects of the paternalistic intervention would be better off. ${ }^{76}$

There is, to be sure, a form of poor judgment claim that has substantial appeal in this context. Poor and uneducated defendants are those who most need good legal advice, yet they probably have the worst lawyers. The defendant's limited understanding and his lawyer's incompetence may produce an awful synergy, which in turn may lead to a bad deal. But-and this is the second problem-abolishing plea bargaining only worsens this situation. Poor people are indeed disadvantaged in the criminal process relative to rich people, but the relative disadvantage increases when trials are required. Trials require greater levels of attorney skill, preparation, and time than plea negotiations. Wealthy defendants can buy more of these commodities than their poorer counterparts.

That is why legitimate concerns about the quality of counsel poor defendants receive in our system do not justify eliminating plea bargaining. Agency problems no doubt exist in this context, particularly in cases of appointed counsel for poor defendants. But the more extended the relationship, the greater the magnitude of those problems. In a world of constant resources, the level of justice for the poor and unsophisticated, relative to the level of justice the rich receive, would decline if plea bargaining were abolished.

\section{Outcome-Based Justifications for Prohibiting Plea Bargaining}

All process-based claims for abolishing plea bargaining run headlong into two obstacles. First, the plea bargaining process more than satisfies the minimum standards set by contract law for the exercise of contractual autonomy. Second, any identifiable defects in the bargaining process seem better addressed by alternative forms of regulation that are more likely than prohibition to ameliorate underlying inequalities. We turn now to a class of arguments that might plausibly avoid these obstacles-arguments that plea bargaining ought

74. See supra note 1.

75. On defendants' desire to accept bargained pleas, sce HeUMANN, supra note 5, at 70-71.

76. Indeed, the primary beneficiaries of prohibition would be those individuals not charged with crimes because prosecutors were required to make more selective charging decisions. As we suggest below, this result is problematic in terms of distributional equity. See infra notes 94-96 and accompanying text. 
to be prohibited not because of flaws in the process, but because of flaws in the outcomes.

\section{a. Contracts of Enslavement}

People cannot make enforceable promises to enslave themselves. ${ }^{77}$ If that familiar restriction on contractual freedom stems from the notion that people should not bargain away too much of their liberty, it casts a large shadow on plea bargaining. Not all plea bargains involve jail time, but many do, and those agreements necessarily involve "sales" by defendants of some portion of their lives, just as would slavery contracts. ${ }^{78}$

There are, however, two critical features of plea bargains that differentiate them from contracts of enslavement. First, while the cost of barring slavery contracts is not high, there are substantial costs to barring consensual allocation in the plea setting. The point of selling oneself into slavery is to convert labor-present and future-into money. But labor (even future labor) can be exchanged for money without enslavement; there is no need to tolerate the deprivation of liberty that slavery entails in order to achieve the would-be slave's goal. Moreover, if parties wish to exchange promises of long-term employment, and bond those promises, they may do so. ${ }^{79}$ The law merely forbids the use of the specific performance remedy. Thus, both the labor-formoney exchange and the bonding mechanism can be achieved without selfenslavement..$^{80}$

Plea bargaining is different. The defendant's liberty is not being traded for something else; rather, a risk of "enslavement" (prison) is being traded for a certainty of somewhat less enslavement. This risk cannot be eliminated in any other way; a defendant who wishes to preclude the possibility of a long sentence can do so only in a system that allows prosecutors to offer shorter sentences in exchange for eliminating costly trials. Abolishing plea bargaining would thus force defendants to bear a risk that they find costly to bear.

That leads to the second point. The background entitlements are completely different in plea bargaining from those in the hypothetical slavery contract. In the plea setting, the government has a probabilistic entitlement to put the defendant in jail before the bargain is struck. The proper analogue to the

77. See Kronman, supra note 27 , at 775.

78. Alschuler, Changing Debate, supra note 4 , at 678-79.

79. One can, for example, create security interests, deferred compensation and pension arrangements, and the like, all of which serve as bonding mechanisms. See Robert E. Scott, A Relational Theory of Secured Financing, 86 CoLUM. L. REV. 901, 927-30 (1986). Indeed, the fact that such bonding mechanisms were much harder to create and enforce centuries ago may account for the historical prevalence of indentured servitude.

80. It follows that most of the people enslaving themselves would be acting irrationally, since they could achieve what they wanted at much less risk to themselves. As Kronman notes, it is easy to justify rules that prohibit a few rational self-interested deals in order to prevent many irrational mistakes. Kronman, supra note 27 , at $768-69$. 
bargaining defendant is not a free man who sells himself into slavery; it is a man who might or might not be a slave (but who does not know, because the issue has not yet been litigated) agreeing to a few years of indentured service in return for freedom afterward. Forbidding such a bargain condemns the mightbe slave to bear the risk of a lifetime of servitude. And that result cannot be justified by mere distaste for the prospect of servitude-the problem exists precisely because enslavement is a permissible outcome. Consequently, if bearing the risk of long-term "enslavement" is costly (as many defendants obviously believe), doing away with the bargains is costly as well. ${ }^{81}$

\section{b. Distributional Justice}

The rules barring enforcement of slavery contracts rest on concerns about the results of particular bargains. But contract also has a tradition of nonenforcement for more systemic reasons, based on how contractual allocation affects the distribution of certain goods and services. A classic example is the nonwaivability of warranties of habitability. As Kronman has noted, this limitation on contractual autonomy seems to rest on society's concern about the distribution of power with respect to fundamental entitlements. ${ }^{82}$ Housing, he maintains, plausibly falls within this category, as do education and health care, two other fundamental goods that are allocated in part through non-market mechanisms. If society regulates the distribution of power over these sorts of entitlements, criminal punishment may warrant the same response.

We do not disagree with this line of argument. Liberty is too important to be allocated by unregulated bargaining. The potential for irrationality and mistake to work irrevocable, life-destroying injustice is too high not to police the bargain. But that is the point-the argument does not imply doing away with plea bargaining; it only implies regulating plea bargains to a greater extent than we regulate other contracts. Kronman's housing example is revealing. The mandatory warranty of habitability does not amount to a prohibition of landlord-tenant contracts; rather, it is a device for after-the-fact policing of such contracts when the terms seem substantively unfair or one-sided. ${ }^{83}$

To some extent, the law governing plea bargaining already polices the bargaining process. Criminal defendants have a nonwaivable entitlement to challenge the substantive constitutionality of the statute under which they were

81. To be sure, one might say that post-trial sentences-the sentences assigned to those who are convicted after refusing to plead-would be lower in a world without plea bargaining, so that the size of the risk being traded is a function of the regime that allows trading to take place. That is no doubt true. If plea bargaining were abolished, the number of trials would increase, and post-trial sentences would necessarily fall, given constant resources. But other aspects of the system would change as well, some in a direction that would increase the risk borne by the defendant facing trial. We discuss these effects at infra text accompanying notes 87-96.

82. Kronman, supra note 27 , at $770-74$.

83. In effect, the nonwaivable warranty of habitability permits courts to revise the quality term of the landlord-tenant contract when that term seems unfair to tenants. 
charged ${ }^{84}$ and there may be some other, similarly nonwaivable entitlements (though almost all rights are deemed waived by the plea). ${ }^{85}$ But this is a poor mechanism for correcting inequitable bargains. The potential unfairness in the typical plea bargain is not that the defendant gives up some legal entitlements, but that he may not get enough from the government in return. Thus, a Kronman-style distributional justice argument would counsel in favor of letting judges revise bargained-for sentences (or sentencing recommendations) downward, in defendants' favor. Judges can currently do this, but they do not exercise the power aggressively. As we discuss below, for a variety of institutional reasons the practice of downward revision ought to be more common than it is. ${ }^{86}$ It bears emphasizing, however, that such a practice entails not the abolition of plea bargaining, but only more intensive judicial scrutiny of bargaining outcomes.

There is another kind of distributional argument one might make against plea bargaining, one that focuses on the distribution of punishment among defendants. Plea bargaining no doubt makes some defendants better off and some worse off than they would be if bargaining were forbidden. The question is whether there is any reason to prefer the combination of winners and losers that plea bargaining generates to the different combination that would be generated by a no-bargaining regime.

84. This is a reasonable extrapolation from Menna v. New York, 423 U.S. 61 (1975), in which the Court permitted a defendant to raise a double jeopardy challenge to his conviction even though he had already pled guilty. For the argument that Menna stands for the proposition stated in the text, see Peter Westen, Away from Waiver: A Rationale for the Forfeiture of Constitutional Rights in Criminal Procedure, 75 MICH. L. REV. 1214 (1977).

There is a plausible argument that Wainwright v. Sykes, 433 U.S. 72 (1977), and its progeny change this conclusion. Sykes holds that claims that are not timely raised according to the governing procedural law (meaning in this context any claim that a defendant seeks to raise after an unconditional guilty plea) can only be raised in subsequent collateral proceedings if there was "cause" for the default, and also if the default "prejudiced" the outcome. Id. at 86-87, 90-91; see also John C. Jeffries, Jr. \& William J. Stuntz, Ineffective Assistance and Procedural Default in Federal Habeas Corpus, 57 U. CHI. L. REV. 679, 681-90 (1990) (describing Sykes doctrine). If Sykes applies to all claims, then the Menna exception, as a practical matter, does not survive. On the other hand, the Supreme Court's retroactivity decisions have stated that the ordinary rule of nonretroactivity does not apply to doctrine that affects the substantive consitutionality of the criminal statute that the defendant was convicted of violating. E.g., Penry v. Lynaugh, 492 U.S. 302, 329-30 (1989). The same exception would likely apply to the Sykes cause-and-prejudice rule.

85. Compare United States v. Broce, 488 U.S. 563 (1989) (defendants who pled guilty to two conspiracy charges were not permitted to raise double jeopardy claim that charges were impermissibly duplicative) with Menna v. New York, 423 U.S. 61 (1975) (defendant's guilty plea did not constitute waiver of double jeopardy challenge to entire charge to which plea was entered). At one time, it seemed that a substantial number of entitlements were not waived by the plea; commentators debated over how the line was to be drawn. See Stephen A. Saltzburg, Pleas of Guilty and the Loss of Constitutional Rights: The Currem Price of Pleading Guilty, $76 \mathrm{MICH}$. L. REV. 1265 (1978); Westen, supra note 84. Today, the category of nonwaivable entitlements appears to be tiny; indeed, it is not clear what it includes, aside from core double jeopardy objections and the entitlement to challenge the constitutionality of the underlying crime. See Menna, 423 U.S. at 62-63 n.2. Moreover, procedural default doctrine may, in practice, shrink the category even further. See supra note 84.

86. See infra text accompanying notes $160-66$. It may be worth noting that no one seems to think that the prosecutor is so powerless that he needs judicial protection on distributional grounds. 
The comparison obviously involves a generous dose of speculation. But one can safely make four basic assumptions about the effects of abolishing plea bargaining. First, the number of trials would increase sharply. ${ }^{87}$ Something in the neighborhood of ninety percent of cases now lead to pleas; if even onethird of those are the result of bargaining, prohibiting plea bargaining would quadruple the number of criminal trials. Second, the error rate of trials would rise. This follows from the first assumption. Trials are elaborate and costly affairs. Any reform that involves a several hundred percent increase in their number must necessarily involve economizing on the process, at least as long as one assumes a constant level of expenditures on the system. Reducing the process, in turn, logically implies increasing the rate of error. ${ }^{88}$ Third, the total number of convictions would fall, probably substantially. ${ }^{89}$ Abolition of plea bargaining would raise the average cost of prosecution because it would increase the percentage of cases that go to trial (and even slimmed-down, cheaper trials will be more expensive than bargained pleas) ${ }^{90}$ Given constant resources, this would mean a drop in the number of convictions. ${ }^{91}$ Fourth, the average sentence would be both higher than the current average bargained-for sentence and lower than the current average post-trial sentence. This last proposition follows from the fact that the number of convictions would decline. If one assumes a constant total level of punishment (meaning no increase in the number of person-years of incarceration) in order to isolate the effects of plea bargaining, spreading a given amount of punishment over a smaller number of defendants means an overall increase in average sentence. At the same time, without bargaining, there is no need for a "premium" sentence to be awarded to defendants who go to trial. Thus, no one (or almost no one) would receive sentences at current post-trial levels. ${ }^{92}$

87. See, e.g., Thomas Church, Jr., Plea Bargains, Concessions and the Courts: Analysis of a QuasiExperiment, 10 LAW \& SOC'Y REV. 377, 383 (1976) (finding sharp increase in trial rates when charge reduction policy in drug cases was abolished).

88. If this statement is not true, then our current process is absurd, and we should radically alter it, regardless of what we do about plea bargaining. In order to isolate the effects of plea bargaining, one must assume that the trial process is rationally constructed.

89. See, e.g., Church, supra note 87 , at 390 .

90. In the most famous discussion of the alternatives to plea bargaining, Stephen Schulhofer examined the use of mini-trials, without juries, as a substitute for plea bargaining in Philadelphia. Schulhofer, Plea Bargaining, supra note 4, at 1062-63, 1083. These trials typically lasted no more than an hour. Id. at 1066 .

It is hard to imagine the system tolerating any more casual mode of adjudication than the Philadelphia trials that Schulhofer observed. But even these require some preparation, and the trial time plainly exceeds the bargaining time in run-of-the-mill cases. Cf. HEUMANN, supra note 5, at 35 (discussing cases in which bargaining takes no more than a few minutes).

91. See Adelstein, supra note 70, at 802 .

92. Given these assumptions, one can make some rough conclusions about winners and losers. Some defendants who are now charged would not be because of the decrease in charges filed. They would get no conviction instead of the current option between a bargained-for low sentence and trial with the possibility of a higher sentence. These defendants would clearly gain from abolition. The other clear gainers would be defendants who now refuse to bargain and are convicted at trial; they would receive either the lower average post-trial sentence, or no sentence at all (depending on whether they were charged). Another set of defendants, who now do plea bargain, would go to trial, get convicted, and receive a sentence higher than the bargained-for sentence they currently receive. They would be clear losers, though not by as large 
Given these effects, there are three factors that suggest abolition might be distributionally less fair than the current regime. First, the defendants who pay the heaviest penalties under the current regime-defendants who refuse to bargain, go to trial, and are convicted-at least have the option, ex ante, of taking a different course of action. The relative losers in a no-bargaining world have no control over their fate; other forces-prosecutorial charging decisions, trial error rates-determine whether they fare well or poorly. To the extent autonomy matters, this should be counted as a cost of abolition.

The second factor concerns the interaction between trial error rates and prosecutorial charging decisions. Prosecutors do not charge in a vacuum; they do so against the backdrop of trial. Because defendants always have the option of forcing a trial, prosecutors have a strong incentive not to press charges in cases that cannot be won. Because error rates at trial would be higher, convicting innocents would likely be easier in a no-bargaining world (just as convicting guilty defendants would be harder). Thus, the incentives to separate the innocent from the guilty at the charging stage would be reduced, meaning that proportionately more innocents would be charged. The reduced cost of trials in a no-bargaining regime would exacerbate this effect: if going to trial were less expensive, the risk of losing at trial would be less costly (because of the reduced opportunity cost), and prosecutors would therefore take fewer precautions against it ${ }^{93}$ In the next part, we discuss the problems that plea bargaining poses for innocent defendants. But it is worth noting that prohibiting plea bargaining would impose additional costs of its own on innocents.

Third, in a world without plea bargaining the average defendant would depend more heavily on his lawyer's expertise: the percentage of trials would sharply increase, and lawyers' skill surely matters more in a trial than in a plea bargaining session, particularly since the latter is likely to be constrained, to some extent, by customary "market" prices. This effect would be particularly pronounced in a trial system with a higher error rate than the current one, and with quicker, more slapdash preparation by the attorneys - a necessary conse-

a margin. Because of the increased error rate of trials, some defendants who are currently convicted would be acquitted, while others who are now acquitted would be convicted. The gainers and losers in these groups would presumably be randomly selected. Finally, to the extent that disincentives to criminal behavior depend more on the certainty of punishment than on its level, e.g., REPORT OF THE NATIONAL ACADEMY OF SCIENCES, DETERRENCE AND INCAPACITATION: ESTIMATING THE EFFECTS OF CRIMINAL SANCTIONS ON CRMME RATES 22 (Alfred Blumstein et al. eds., 1978) [hereinafter DETERRENCE AND INCAPACITATION]; George Antunes \& A. Lee Hunt, The Impact of Certainty and Severity of Punishment on Levels of Crime in American States: An Extended Analysis, 64 J. CRIM. L. \& CRIMINologY 486, $492-93$ (1973); Isaac Ehrlich, Participation in Illegitimate Activities: $A$ Theoretical and Empirical Investigation, $81 \mathrm{~J}$. POL. ECON. 521, 544-47 (1973), there would be some loss of general deterrence, which would fall on the public. This is because a no-bargaining regime would involve the same total amount of punishment, but punishment would be distributed in a more concentrated manner.

Whatever one thinks about the incidence of these various effects, we see no principled basis for preferring the winners from abolishing plea bargaining to the losers.

93. That is, prosecutors would not simply proceed with their strongest cases and drop their weakest ones, since the incentive to separate strong from weak cases would be reduced. 
quence of vastly increasing the number of trials. The increased impact of skill differences among attorneys would adversely affect poor defendants, since they tend to have the worst lawyers. Thus, there is some ground for believing that a world without plea bargaining would disproportionately harm both the innocent and the poor, hardly a recipe for a more distributionally just system.

The one large counterweight to these effects is the likelihood that a substantially smaller number of cases would proceed to final disposition. That likelihood implies that the absolute number of innocents who are punished might decline in a no-bargaining regime, though the proportion of such defendants would probably rise. But there is a more unpleasant possibility: if low-cost case-processing methods such as plea bargaining were unavailable, police and prosecutors might dispense low-level punishment informally, without substantial legal regulation. Brief detentions incident to arrest might, in some cases, serve as a substitute for more formal proceedings. This prospect can hardly be a boon to the innocent. And even if there were an absolute decline in the number of innocent defendants punished (due to the substantial decline in the total number of defendants punished), that decline would have its own distributional consequences. The loss of certainty of punishment would lead to a loss of deterrence, ${ }^{94}$ the cost of which would appear as a tax on the citizenry. To be more precise, it would be a tax on those portions of the citizenry that most feel the effects of crime - once again, those who inhabit poorer neighborhoods. ${ }^{95}$ All in all, it is hard to argue that these effects would enhance distributional justice, on any sensible vision of what that phrase means. ${ }^{96}$

\section{Summary}

We have tried to show that the objections to plea bargaining as an institution are not grounded in the norms of contract law-at least not as that law is conventionally understood. Contract norms might justify some constraints, both to reduce the risks of process defects and to enhance the dignitary values associated with an exchange involving the entitlement to personal liberty. On the other hand, classical contract theory plainly supports a presumption in favor of enforceability.

This conclusion does not, however, lay the debate to rest. The intuition that drives critics of plea bargaining is worthy of careful scrutiny even if it cannot

94. See infra note 105.

95. See, e.g., Ehrlich, supra note 92 , at 545.

96. One of us. has suggested an application of superfaimess theory as a criterion for determining distributional fairness. See Scott, supra note 61 , at 782-86. Superfaimess analysis seeks to measure the equity or faimess of any particular distribution solely in terms of the preferences of the persons involved. Under this conception, a distribution is fair if no class of participants would regard its own share as less valuable than the share received by another group. See WILLIAM J. BAUMOL, SUPERFAIRNESS: APPLICATIONS AND THEORY (1986). Applying the superfairness criterion to the abolition of plea bargaining confirms the intuition that the losers from the change would envy the distribution received by the winners. In that sense, therefore, the superfaimess criterion would not be satisfied. 
be grounded in contemporary contract law. In the next part, we approach the problem from a somewhat different angle (though one that is also grounded in contract), and look at the plea bargaining dynamic through the lens of bargain theory.

\section{Plea Bargains AND Bargain Theory}

The bargain theory of contract has dominated American jurisprudence for well over a hundred years. Its remarkable durability rests on a single idea: contracting parties can (and do) reach mutually beneficial agreements that fully exploit the potential returns from their joint enterprise. ${ }^{97}$ But many private contracts do not fit this simple model. The assumption that contracting parties will reach mutually advantageous and efficient bargains (so long as transaction costs are less than the gains from trade) ignores significant barriers to efficient contracting, barriers found in a wide variety of relationships. Despite the parties' seeming ability to transact at low cost, strategic considerations may block the disclosure of necessary information or inhibit the development of the kinds of credible commitments that are needed for the relationship to go forward.98

For a large number of plea bargains, probably the great majority, these obstacles do not exist, and there is no mystery about what drives the bargain. Criminal trials are costly for defendants, and even more so for prosecutors. These costs can be saved, and the gains split between the parties, by reaching a bargain early in the criminal process. Consequently, in cases where both parties understand that conviction at trial is virtually certain-a description that fits many, many cases ${ }^{99}$ - the incentive to bargain is simple. Savings in adjudication costs represent the gains from trade.

The picture is more complicated, and more interesting, in cases where the likelihood of conviction is less clear-including, though not limited to, cases where the defendant is innocent. In this part, we discuss the bargaining dynamic in such cases, using some of the techniques of modern decision analysis. This approach yields two key points: (1) parties bargain over the allocation of criminal punishment in order to reassign and thereby reduce the risks of an uncertain future, and (2) strategic considerations will often prevent these parties from reaching an efficient contract that fully exploits potential gains. The first point supports the argument that a prohibition on plea bargaining would impose

97. See Scoth, supra note 17 , at 2010.

98. On the idea of strategic barriers to efficient contracting, see Ayres \& Gertner, Filling Gaps, supra note 13, at 99-104; Ayres \& Gertner, Strategic Contractual Inefficiency, supra note 13, at 729-46; Charles J. Goetz \& Robert E. Scott, The Mitigation Principle: Toward a General Theory of Contractual Obligation, 69 VA. L. REV. 967, 981-84 (1983); Johnston, supra note 13, at 616-26; Scoth, supra note 13, at 608-13.

99. See HEUMANN, supra note 5, at 58, 60-61 (noting that new defense attorneys quickly learn that most of their clients are not only guilty, but lack any plausible defense). 
net social costs. The second point implies that carefully crafted legal rules are necessary to lessen the effects of strategic bargaining.

\section{A. The Risk Exchange}

The dynamic of plea negotiations is complex. Clarifying the process requires a good deal of abstraction in order to isolate the most important variables. To that end, we begin with several simplifying (and artificial) assumptions. First, we assume that the parties can only negotiate in one of two periods, $T_{1}$ and $T_{2}$. $T_{1}$ occurs shortly after the charging decision. $T_{2}$ occurs at the conclusion of trial, but before the jury has reached its verdict. Second, we assume that the administrative costs of proceeding to trial are low. Third, we assume that the probabilities and magnitudes of all exogenous contingencies (such as risk of a change in the substantive criminal law) will remain constant throughout both periods. Fourth, we assume that defense counsel perfectly represents his client's interests, which are defined as the minimization of punishment. Finally, we assume that the prosecutor's objective is to maximize punishment.

Given these limiting assumptions, the first question is what the parties stand to gain by bargaining. The obvious answer is that there may be gains from reassigning endogenous risks-that is, risks of future events over which they have some control. This might include, for example, decisions about gathering additional evidence, interviewing witnesses, and requesting a jury trial. To be sure, many of the contingencies that will affect the likelihood of conviction are too uncertain to allow either party to make decent predictions. Still, the parties can make some assessments because some contingencies are easily foreseeable. How then might two parties engaged in plea negotiations-Prosecutor $(P)$ and Defendant $(D)$-distribute the risk of these foreseeable contingencies?

The key is understanding the nature of the assessments $P$ and $D$ must make. $P$ knows the initial strength of her case, based on her experience, her judgment, and the facts at hand. $D$, meanwhile, knows something of $P$ 's case, but not much, given constraints on discovery. ${ }^{100}$ On the other hand, $D$ has a major

100. Defendants are not permitted open access to prosecutors' files, though they are permitted some discovery, and prosecutors must disclose the bare bones of their case. See, e.g., Eleanor J. Ostrow, The Case for Preplea Disclosure, 90 YALE L.J. 1581 (1981). Most important for purposes of plea bargaining, the police report-the primary source of information for the frosecutor about the case-is not ordinarily discoverable, except at the prosecutor's discretion. See FED. R. CRIM. P. 16(a)(2); 2 WAYNE R. LAFAVE \& JEROLD H. ISRAEL, CRIMINAL PROCEDURE $\$ 19.3$, at 498-500 (1984). Thus, at the time of settlement negotiations, a criminal defendant has much less knowledge of the government's case than, say, a civil defendant has of a civil plaintiff's case against him. While it is true that prosecutors too are limited in their knowledge of the case at the time of negotiations, prosecutors may have substantial knowledge of matters that do not appear in the file, such as information picked up through conversations with the investigating officer.

Some formal analyses of plea bargaining misunderstand this point, and hence proceed from the mistaken assumption that the nature and quality of the government's case is equally available to the prosecutor and the defense attorney. See, e.g., Gene M. Grossman \& Michael L. Katz, Plea Bargaining and 
piece of information that $P$ does not: $D$ knows whether or not he is guilty. ${ }^{101}$ Based on the different packages of information each side has, both must generate an estimate of the likelihood that $D$ will be convicted if the case goes to trial. That estimate will determine the price that each will insist on as a condition of reaching a bargain at $T_{1}$. The probability of conviction is, in turn, a function of (among other things) two factors: (1) the strength of $P$ 's case, which $P$ knows well but $D$ knows incompletely, and (2) the likelihood that $D$ is in fact innocent, which $D$ knows but $P$ does not. Though related, these two factors are distinct. The strength of the case is based upon the evidence available to $P$ from sources other than $D$. $D$ 's factual guilt or innocence depends on $D$ 's own conduct and intent-that is, on historical facts that are only partially revealed by the evidence, but that $D$ typically knows. ${ }^{102}$

The relevance of this last factor is important, and not altogether obvious. The likelihood that $D$ will be convicted is (one hopes) strongly correlated with $D$ 's actual guilt or innocence: in general, innocent defendants can more easily find evidence that exonerates them (or that casts doubt on the government's theory of the case) than guilty ones can. This is obviously true in cases of simple mistaken identity, but it is also true in more subtle cases of innocence, as where $D$ committed the act charged but lacked the requisite mens rea, or where he has a valid claim of self-defense. One who killed accidentally or in self-defense may not be able to prove his innocence at the time of charging, yet there is a substantial likelihood that with enough legwork (and brainwork), his attorney can make the necessary showing at trial. What $D$ actually did and thought thus bears powerfully on any prediction about what evidence is likely to come out during the course of further investigation. And guesses about yetto-be-discovered evidence are in turn critical to the parties' assessments of the odds of conviction at trial. But $P$ does not know whether $D$ is innocent or guilty; $P$ knows only what is in her files, together with whatever she may have picked up through casual conversation with the arresting officer. $D$, on the other hand, does know.

Social Welfare, 73 AM. ECON. REV. 749, 751-52 \& n.11 (1983).

101. This knowledge can take several different forms. $D$ surely knows if the state has charged the wrong man, since $D$ is aware of his noninvolvement in the crime. But the point also applies to cases in which $D$ was indeed involved, but lacked the requisite criminal intent, or perhaps has a valid defense to the charge. In these cases, $D$ may not completely understand his own innocence, because he may not understand the legal standards against which his conduct and intent are to be measured. But he at least knows what he did and what he thought when he did it-the historical facts that provide the basis for any subsequent determination of innocence or guilt.

102. For a formal model of plea bargaining based on this exchange of private information, see Jennifer F. Reinganum, Plea Bargaining and Prosecutorial Discretion, 78 AM. ECON. REV. 713 (1988). Reinganum's analysis focuses on the effect on plea bargaining of prosecutors' ability to dismiss charges. Her conclusion is that the prosecutor has substantial incentives to dismiss weak cases rather than take them to trial. We agree with this conclusion. Our analysis in this part is addressed chiefly to a different set of defendants: those against whom the prosecutor has a "winnable" case, but who would be acquitted if the judge and jury had perfect information. 
With these factors in mind, one can begin to see the parties' incentives to bargain. Start by asking what might cause either party to regret not striking a deal at $T_{1}$. In the event that a bargain is not reached, the two sides bear reciprocal risks of price fluctuations. $P$ bears the risk that she has overestimated the likelihood of conviction-that, when all the evidence is out at $T_{2}$, the defendant's case will look much stronger, or the government's much weaker, than she thought at $T_{1}$. This change would mean a change in the price of the plea, and obviously, the direction of the change is downward, meaning that $P$ would have done better to bargain at $T_{1} . P$ thus bears the risk of downward price movement from $T_{1}$ to $T_{2 .} D$, meanwhile, bears the opposite risk - that he has underestimated the odds that the jury will convict him; or in other words, that the government's evidence is more powerful, or his own less so, than he had thought at $T_{1}$. This change moves the price of a plea upward. $D$ thus bears the risk of upward price movement.

The plea bargain at $T_{1}$, like any ordinary fixed-price executory contract, exchanges these risks. Setting the price at $T_{1}$ means that $P$ would no longer regret her decision if the price fell from $T_{1}$ to $T_{2}$. Regret is now triggered only if the government's case is stronger (or the defendant's weaker) at $T_{2}$ than she had guessed at $T_{1}$. $P$ thus bears the risk that the price of a plea will rise. The analysis for $D$ is reciprocal. He now bears the risk that the price will fall, and thus that he could have gotten a better deal if only he had waited.

Why would the parties wish to exchange these risks? Why would $P$ prefer to bear the risk of price increases and $D$ the risk of price declines, rather than the other way around? The answer is that by shifting the risks of price changes, those risks will be reduced, and both parties can share in the resulting benefits. And there are several possible strategies for reducing risk that, singly or in combination, can motivate $P$ and $D$ to agree to bind their $T_{2}$ actions with an agreement at $T_{1}$.

The first strategy is risk transfer-reducing risks by reallocating their consequences. This strategy does not depend on differences in knowledge or ability to influence events, but on the parties' subjective risk preferences. ${ }^{103}$ Suppose that $D$ is risk averse and $P$ is risk neutral. If that is the case, the risk that future information might cause the $T_{2}$ price to rise may be more costly for $D$ to bear than for $P$, not because $P$ can reduce it, but because she attaches less cost to bearing it than $D$. But while this phenomenon may explain some of the motivation for plea bargains, it is probably not the dominant risk distribution strategy. The mere fact that $P$ and $D$ have different utility functions does not

103. In this case, the parties attach different subjective values to what is objectively the same risk. If the risk is not already allocated to the party who places the lowest monetary cost on it, then a transfer to that party, with appropriate compensation paid to the bearer of the risk, will be mutually advantageous. Risk transfer thus reduces risk costs when an otherwise unchanged risk is allocated to one party (here $P$ ) who, if only for psychological reasons, places a lower monetary value on the risk. See CHARLES J. GOETZ, CASES AND MATERIALS ON LAW AND ECONOMICS 123-27 (1984). 
necessarily imply a difference in risk preference. Prosecutors, unlike defendants, can diversify somewhat, and their capacity to do so suggests either risk neutrality or a low level of risk aversion. Defendants, for their part, may have a low level of risk aversion for other reasons. At least among guilty defendants (surely the large majority), ${ }^{104}$ their out-of-court behavior suggests a form of "gambling" that is inconsistent with a strong assumption of risk aversion. ${ }^{105}$

But a negotiated bargain at $T_{1}$ can reduce risks even if both parties are risk neutral. The probability of conviction is determined, in part, by private information controlled (or partly controlled) by each party. Thus, either party can alter the objective amount of risk that both face. This potential gain to both sides can be realized if they agree to assign the responsibility for undertaking appropriate precautions to the party best able to influence the magnitude of the risk. ${ }^{106}$

Using this strategy of risk control, $P$ and $D$ would bargain to assign the risk of a given price change to the party who has the best access to the kind of information that might trigger such a change. A major component of the risk of price decline is $D$ 's innocence. Since $D$ knows whether he is innocent, he is well positioned to guard against overly high assessments of the likelihood of conviction. Thus, the risk of price decline is less if borne by $D$ than if borne by $P$. Similarly, the principal risk of a price increase derives from new facts that enhance the strength of the case. As the party who controls investment in the strength of the case, $P$ can better avoid unanticipated increases in the probability of conviction.

It is tempting to argue that the risks are reciprocal, so that neither party can systematically benefit from shifting them. If this were so, the risk of a price decline could not be meaningfully reduced if borne by $P$, nor could $D$ predictably control the risk of a price increase. This argument erroneously assumes,

104. Of course, it is impossible to know what proportion of defendants are factually guilty. We do know, however, that between three-fourths and four-fifths of those who go to trial are convicted. From that and other figures, one can fairly surmise that a large portion, probably a large majority, of those who plead guilty would have been convicted had they gone to trial.

For an interesting attempt to get to the bottom of this question, see MICHAEL O. FINKELSTEIN, QUANTITATIVE METHODS IN LAW 265-83 (1978). Finkelstein analyzed the relationship between guilty pleas and overall nonconviction rates; his analysis yielded the conclusion that, in federal courts in the 1970's, at least one-third (but clearly less than half) of those who pled guilty would have been acquitted at trial. $I d$. at 280 . The analysis suggests different conviction rates for different time periods, however; it is not clear what rate would apply to typical state jurisdictions today.

105. That is why, according to the conventional wisdom, certainty of punishment is more important than the level of punishment. See Daniel Nagin, General Deterrence: A Review of the Empirical Evidence, in DETERRENCE AND INCAPACITATION, supra note 92, at 95-111 (summarizing the data); sources cited supra note 92 . Note that this risk preference is, in itself, a strong argument in favor of plea bargaining: if criminals tend to be gamblers, cost-effective deterrence is likely to require apprehending a large portion of them, rather than punishing a few at much higher rates. Plea bargaining allows the system to maximize the number of defendants who receive punishment, because it minimizes the unit cost of prosecution by amortizing the expense of each trial over 10 or more cases.

106. For an elaboration of this argument, see Charles J. Goetz \& Robert E. Scott, Liquidated Damages, Penalties and the Just Compensation Principle, 77 COLUM. L. REV. 554, 578-83 (1977); see also GOETZ, supra note 103 , at 127. 
however, that at $T_{1}$ the risks of conviction and acquittal are approximately the same. But, of course, this is not the case. Since $T_{1}$ occurs after the charging decision has been made, the risk of conviction is substantially greater than the risk of acquittal: about three-fourths of trials yield convictions, and for every trial there are eight to ten guilty pleas. ${ }^{107}$ The key question is whether $D$ has a comparative advantage in reducing the risk of a marginal decline in the probability of conviction. And he does, since his private information cuts more heavily in one direction-toward acquittal-than the other. Similarly, $P$ 's private information, which is linked to $P$ 's investment in preparing her case, disproportionately affects the post-charging probabilities of conviction. Thus, $P$ is able, by controlling her investment in the case, to bear at less cost the risk of any increase in price from $T_{1}$ to $T_{2}$.

In sum, exchanging risks of price fluctuations reduces those risks. This is a powerful theoretical justification for the claim that a bargain between $P$ and $D$ at $T_{1}$ can generate net social gains. The next question is whether strategic bargaining problems impair the information exchange between $P$ and $D$, and thereby distort $T_{1}$ bargains in a way that might undermine this optimistic assessment.

\section{B. The Problem of Information Deficits}

Thus far, we have assumed that if $P$ and $D$ reached a deal at $T_{1}$, the bargain would fully exploit the potential gains from risk reduction. That assumption is a common one in many contexts: where gains from trade exceed transaction costs, the parties can generally reach an efficient allocation of risks and entitlements. But the assumption of efficient contracting breaks down where the contracting parties cannot reliably exchange important information. ${ }^{108}$ In this section, we explore a particular obstacle to information exchange, an obstacle that tends to generate mistakes and bargaining breakdown, especially in cases involving innocent defendants.

\section{Plea Bargaining with Costly Adjudication and Full Information}

We begin by relaxing one unrealistic assumption-that going to trial is not very costly-and introducing two others: (1) each party can costlessly evaluate the truthfulness of the other's statements, and (2) rules against misrepresentation

107. See supra notes 1,3 .

108. See Ayres \& Gertner, Filling Gaps, supra note 13, at 97-107; Robert Cooter, The Cost of Coase, 11 J. LEGAL STUD. 1, 20-24 (1982); Scott, supra note 17, at 2031-39. In the economics literature, the problem of asymmetric information inducing inefficient contracting was first established by George $A$. Akerlof, The Market for "Lemons": Quality Uncertainty and the Market Mechanism, 84 Q.J. ECoN. 488 (1970); see also Roger B. Myerson, Mechanism Design by an Informed Principal, 51 ECONOMETRICA 1767
(1983). 
can be costlessly enforced. These moves are designed to expose the role of adjudication costs and information exchange in shaping plea bargains.

The significance of adjudication costs is fairly clear. As we saw in Part $\mathrm{I},{ }^{109} D$ has a call on $P$ 's time. The decision to go to trial is not simply a lost bargain for $P$; it imposes a substantial cost in time and energy. To put it differently, adjudication costs are both high and disproportionately allocated to prosecutors. Prosecutors bear the burden of proof and therefore must invest more in digging out and presenting evidence. ${ }^{110}$ Defendants have a lesser burden of producing evidence; moreover, they often do not internalize their own cost of legal representation. ${ }^{11}$

The point of assuming free information exchange, meanwhile, follows from our discussion in the last section. The defendant's knowledge of what he did and thought-that is, his knowledge of whether he is guilty or not-is a good predictor of future evidentiary discoveries, and hence powerfully relevant to whether he will be acquitted or convicted. Prosecutors would thus like to know this information, whether or not they are altruistically concerned with avoiding injustice. Here, we ask how the parties would accommodate this desire if they could. We can then discuss the barriers to disclosure that prevent them from doing so.

Note the effects of these assumptions on $P$ 's bargaining strategy. First of all, asymmetric adjudication costs mean that $P$ 's reservation price is lower than it would be otherwise. ${ }^{112}$ In other words, the sentencing differential-the gap between the sentence offered at $T_{1}$ and the sentence imposed after trial and conviction-must be large enough to reflect $P$ 's costs. Introducing adjudication costs into the dynamic thus raises the cost of going to trial (or, in relative terms, lowers the price of a plea) to $D .{ }^{113}$ For the same reason, adjudication costs explain why the parties might reach a bargain even in cases where both sides are virtually certain that the defendant will be convicted at any subsequent trial and have a good idea what the resulting sentence will be. Because adjudication costs are disproportionately visited on prosecutors, prosecutors will offer pleas at a price that allows defendants to share in some of the cost savings.

But in a world of full information, prosecutors have a strong incentive to vary the prices they charge. Remember that $P$ is not competing with other prosecutors for customers; rather, she is trying to generate the optimal number

109. See supra text accompanying notes 55-58.

110. Thus, it is possible for defendants to win without putting on a "case" of their own, and in all but a very small number of cases, the government's case is more elaborate and extensive than the defense.

111. The defendant has still another advantage: he may be a more efficient evidence-gatherer: he has a comparative advantage in knowing where to look for evidence since he knows what he did.

112. For a formal analysis and proof, see David Rosenberg \& Steven Shavell, A Model in Which Suits Are Brought for Their Nuisance Value, 5 INT'L REV. L. \& ECON. 3 (1985). The central idea is that where one side's litigation costs are higher than the other's, and where both sides know of the disparity, the difference in litigation costs should be incorporated into the settlement price.

113. The cost of going to trial is thus inversely related to the price of pleading. 
of pleas among the defendants assigned to her. ${ }^{114}$ In order to do that effectively, she must take account of the probability of conviction at trial. That is, she must offer different prices to defendants who are fairly likely to win at trial than to defendants who are sure to lose. These different prices would then induce innocent defendants to reveal the key private information-their historical knowledge - that determines, in part, the value of the bargain. In other words, $D$, if innocent, has every reason to signal that fact to $P$, and $P$ has every reason to pay attention to the signal.

Naturally, guilty defendants would like to take advantage of the price difference, and would thus try to copy the signal. But in a regime where lies can be costlessly detected, $P$ can easily prevent this kind of behavior simply by punishing misrepresentation. The innocent and the guilty will be perfectly separated in the bargaining process.

Note that this is true even if (1) trials sometimes convict innocent defendants, and (2) prosecutors are wholly unconcerned about whether such defendants get punished. We have assumed that $P$ does not in fact care whether $D$ is innocent, but cares only about maximizing punishment at minimum expense. Most real-world prosecutors would dismiss charges in response to a verifiable claim of innocence from a defendant. Our point is that, given full information, even selfish and amoral prosecutors have an incentive to take innocence (or the possibility of innocence ${ }^{115}$ ) into account in bargaining.

\section{Introducing Information Barriers}

In the real world, prosecutors cannot costlessly test defendants' claims of innocence, nor can they costlessly punish false claims. This has a powerful effect on $P$ 's pricing strategy. $P$ still has market power and can still set prices according to different defendants' willingness to pay. But now $P$ has a problem if she offers a different price to defendants who claim innocence than to defendants who do not: the latter category will disappear. ${ }^{116}$ Guilty defendants, faced with two prices for pleas-a high probability of conviction/high price and a low probability/low price-will opt for the lower one. If innocence claims are not costly (because false claims are hard to detect definitively, and

114. This means $P$ can price discriminate without fear of being undercut by a competitor, since there are no direct competitors.

115. It is worth emphasizing that the analysis holds true even if defendant's claim is only incompletely verifiable-that is, if the prosecutor can know only that there is a higher-than-random likelihood that the defendant is innocent.

116. Kenneth Mann notes that the reverse phenomenon occurs in white-collar cases. Defense counsel in white-collar cases often enter the picture during the investigation, before final charging decisions have been made. Any initiation of plea bargaining by suspects during this stage is taken by the government as a signal that the suspect must be guilty of something, and hence should be charged. The consequence is that defense lawyers say and do nothing to indicate that they might expect charges to be filed until the charges actually are filed (or are certain to be). KENNETH MANN, DEFENDNG WHITE-COLLAR CRIME 14-16 (1985). 
expensive to punish), and if such claims generate a better deal for defendants, all defendants will say they are innocent. In order to overcome this problem, one of two things must happen: either prosecutors must devise some screening mechanism for testing innocence claims, or innocent defendants must devise some method of signaling their innocence.

In some circumstances, the trial itself might function as the necessary screen. If innocent defendants are never convicted, then the rational bargaining strategy for innocent defendants is to insist on dismissal of all charges. That is, such defendants should simply refuse to bargain, since going to trial would be risk-free. ${ }^{117}$

Unfortunately, trials make mistakes. Some innocent defendants-no one knows how many-are convicted. And since prosecutors have some incentive to proceed only with cases they can win, any innocent defendant faced with formal charges must consider the possibility that he might lose at trial. This would not be disabling if guilty and innocent defendants had the same level of risk aversion. Were that the case, $P$ could offer a high probability/high price contract that only guilty defendants would accept. But that is probably not the case. We noted earlier that defendants as a class are unusually prone to risk taking. That statement is true of guilty defendants: a criminal history suggests a preference for gambling, just as it suggests that the defendant fears punishment less than most people. But risk aversion is a much more plausible assumption where innocent defendants are concerned (especially those with relatively clean records). ${ }^{118}$ Given a higher level of risk aversion among innocent defendants than among guilty ones, the high price/high probability contract will often prove attractive even to the innocent.

Although the need to find some separating mechanism remains, the obvious possibilities do not work. $P$ might wish to have an enforceable side contract that would deter false claims, so that if $D$ were later shown to have lied, he could be severely punished for it. $D$, if innocent, might wish to enter into such a contract in order to bond his claim. But the side deal is too costly to enforce. Proving that $D$ lied amounts to proving $D$ guilty of the offense; in other words, it amounts to taking the case to trial. Thus, even with the side deal, $P$ must choose whether to agree to a plea or (functionally) go to trial, without knowing whether $D$ 's claim of innocence is true. This problem might be surmounted by raising the penalty for lying: if false claims of innocence at the bargaining stage were punishable by death, one might be able to deter false claims. But stating the scheme explains why it is impossible. The punishment must be set so high

117. This is the basic insight of Grossman \& Katz, supra note 100 . They show that, given a sufficiently high likelihood of acquittal of innocent defendants at trial and given certain assumptions about risk preferences, plea bargaining itself functions as an effective device for separating innocent from guilty defendants, because innocent defendants always find it in their interest to insist on going to trial. 715.

118. For anecdotal support for this proposition, see Alschuler, Changing Debate, supra note 4, at 685, 
that it would conflict with basic criminal law norms of proportionality. The system would be unwilling to carry out such harsh threats, and the threats themselves would soon become empty.

\section{Extralegal Responses to Information Barriers: Reputation and Other Signaling Mechanisms}

There are other ways for parties to reduce the cost of acquiring reliable information from each other. A party might, for instance, use an established reputation to bond his claims, if the reputation suggests that he lives up to his word. ${ }^{119}$ In the plea bargaining context, the past record of the defendant can serve this function, though only in a negative sense. If $D$ is charged with armed robbery, a substantial record of burglary and robbery charges and convictions might be a reliable signal that $D$ should get the high price/high probability of conviction contract. Evidence of a bad reputation would signal that $D$ 's innocence claim can be substantially discounted. ${ }^{120}$ The problem is that the signal fails to screen those whose past records are clean. In other words, the ability to screen for a bad reputation has no bearing on establishing a good reputation. Among the pool of defendants who have no prior record, some will be innocent and some guilty, and the prosecutor has no a priori means of separating the wheat from the chaff.

Other methods of extralegal signaling are even more suspect. For example, a common method of signaling reliability in commercial contracts is "labeling"-making assumptions based on fixed characteristics of other parties that can be easily observed when the interaction begins. Janet Landa has shown the value of labeling for ethnically homogeneous Chinese middlemen who rely on immutable characteristics such as familial identity and dialect. ${ }^{121}$ Other commercial parties form trade associations that promulgate ethical norms for contracting behavior. ${ }^{122}$ And parties sometimes adopt territorial strategies, using patterns of bargaining with "neighbors" as a substitute signaling technique. ${ }^{123}$ None of these devices can be relied upon by prosecutors and defendants to overcome their information barriers.

119. If the market for contracting partners is thick, each party has a positive incentive to establish a reputation for credibility and work to engage in future contracts. The key in a well developed market, therefore, is the ability of each party to choose a partner. Sie Gordon Tullock, Adam Smith and the Prisoners' Dilemma, 100 Q.J. ECON. 1073 (1985). In the "thin" market like the one that operates in plea bargaining, the choice among partners is limited and reputation is a less potent method of signaling credibility. See Goetz \& Scott, supra note 98 , at 1013.

120. Moreover, $P$ can fairly conclude that even in the unlikely event that $D$ is innocent of the crime charged, he has almost certainly committed many comparable offenses that have gone undetected. Thus, even if $P$ is concerned about minimizing injustice, he should perhaps disregard worries about $D$ 's innocence in these cases.

121. Janet T. Landa, A Theory of the Ethnically Homogeneous Middleman Group: An Institutional Alternative to Contract Law, 10 J. LEGAL STUD. 349, 358-60 (1981).

122. Scott, supra note 17, at 2033.

123. ROBERT M. AXELROD, THE EVOLUTION OF COOPERATION 158-68 (1984). 
$P$ and $D$ could conceivably signal the reliability of private information by using transaction-specific devices. Commercial parties often solve the problem of trust by offering to pledge assets as collateral for a promise that representations are reliable. ${ }^{124}$ Alternatively, the relevant party can agree to pay a substantial monetary penalty in the event of breach. Neither of these common strategies are available in most plea settings, since most defendants lack the assets needed to make the strategies work.

\section{Norms, Ethics, and Other Substitutes for Signaling}

Scholars have long recognized that group norms and individual ethics can play an important role in regulating contractual relationships. In many commercial environments, norms such as honesty, promise-keeping, trust, and solidarity reinforce the credibility of contractual commitments. ${ }^{125}$ These norms may add more value than legal enforcement. But the plea bargaining context is not well suited to this method of bonding representations. For group norms to work, the contracting parties must share the same norms. Not only are criminal defendants likely to be more heterogeneous than other groups of contracting parties, but defendants as a class reject the norms of trust and promise-keeping in their relations with prosecutors. Since bargaining takes place very early in the process, the prosecutor cannot know whether any particular defendant is trustworthy; if there is no effective penalty for lying, she must treat all claims of innocence as false.

One might think defense counsel could help solve this problem. Lawyers are classically attentive to group norms, and in this setting, the same lawyers tend to deal with each other in many different cases, which adds to the incentive to adhere to whatever values or norms the group finds useful. But there are two obstacles to using defense counsel to bond a defendant's claims. First, the defendant's lawyer typically knows little more than the prosecutor about the defendant's trustworthiness. The second obstacle only aggravates the first. In any system that used defense lawyers to screen good from bad claims of innocence, guilty defendants would abandon candor with their lawyers-as many do anyway. ${ }^{126}$ Thus, the trustworthiness of the defendant's lawyer cannot convince the prosecutor of the trustworthiness of the defendant's claim of innocence.

124. See Anthony T. Kronman, Contract Law and the State of Nature, 1 J.L. ECON. \& ORGANIZATION 5, 12-15 (1985).

125. See Robert C. Ellickson, A Critique of Economic and Sociological Theories of Social Control, 16 J. LEGAL STUD. 67, 92-93 (1986). See also Stewart Macaulay's classic study of contractual behavior among business firms. Stewart Macaulay, Non-contractual Relations in Business: A Preliminary Study, 28 AM. SOC. REV. 55, 63 (1963).

126. See HEUMANN, supra note 5, at 59-60. As one of the defense attomeys Heumann interviewed stated: "[T]he first year you practice law you believe everything your client tells you. The second year you practice, you believe everything that the other side tells you. The third year you don't know who's telling the truth. Most people tend not to believe their clients that much, justifiably." Id. at 59. 


\section{Signaling by Refusal to Bargain}

An innocent defendant does have one available device for signaling innocence: he can refuse to accept the high price/high probability-of-conviction contract, saying, in effect, "I'll take my chances at trial." It is tempting to regard this refusal as an effective indicator, since the defendant has the comparative advantage in knowing what as-yet-undiscovered evidence will come out at trial. If his estimation of the probability of conviction is lower than the prosecutor's reservation price, the defendant may well be innocent.

The problem, again, is that the prosecutor cannot prevent guilty defendants from copying the signal. If innocent defendants refuse to bargain and prosecutors respond by making low price/low probability-of-conviction offers, guilty defendants will respond, in turn, by being initially intransigent in order to secure the same deal for themselves. For essentially the same reason, the prosecutor cannot offer a menu of variable sentences after substantial trial preparation has gone forward. That approach would lead other defendants to try to push their cases further toward trial (and thereby raise the cost of processing those cases) in order to get better deals. Indeed, far from wishing to screen out innocents at a late stage, the prosecutor's probable strategy is to punish defendants who force a great deal of trial preparation before they plead. ${ }^{127}$ Refusals to bargain may, in short, be good signals, but prosecutors have strong incentives not to pay attention to them.

\section{The Effects of the Information Problem}

In the absence of reliable signals that they can afford to take seriously, prosecutors have no viable option other than to ignore claims of innocence. That is not to say that they do not care about those claims. On the contrary, prosecutors must take into account the odds of acquittal when making plea offers. Thus, defendants who can at $T_{1}$ point to evidence that supports their innocence claims can either obtain a dismissal or a favorable plea offer. But in assessing the odds of acquittal, the prosecutor has strong incentives to consider only the information available to her at the time of bargaining, and not to investigate or otherwise credit the defendant's claims.

127. To be sure, Heumann notes that on some occasions, defense attorneys were able to extract significant concessions by pushing the case toward trial. Id. at 73-74. The most plausible explanation for these cases-the only one that is consistent with the dominant pattern of punishing defense attorneys for stringing out the litigation-involves a form of prosecutorial bluffing. If $P$ recognizes at $T_{1}$ that her case is weak, she may nevertheless take a strong bargaining position in the hope that defense counsel will relent and accept the too-harsh deal. A shrewd defense lawyer may call $P$ 's bluff in such a case, prompting $P$ to make last minute concessions in order to avoid a trial. The key to this interaction is $P$ 's belief in the weakness of her case at $T_{l}$. In the more typical case, where P's assessment at $T_{1}$ is more favorable, an aggressive defense strategy, one that involves filing a series of motions, pushing the case toward trial, or both, yields only prosecutorial retaliation. Id. at 122-26. 
This notion might seem obvious, and not terribly troubling. Of course prosecutors do not credit claims of innocence in plea bargaining; if they did, they would simply dismiss charges. But our analysis applies more broadly. For all the reasons that some subset of innocent defendants cannot signal that they are innocent, they also cannot signal that they might be. Prosecutors have an incentive to avoid any price adjustment that might lead to strategic behavior by guilty defendants. Moreover, the argument applies not only to defendants who are guilty of nothing, but also to defendants who are guilty of a crime less serious than the one charged. ${ }^{128}$ That is, the theoretical argument has been framed in absolute terms, but it applies to relative differences as well. Finally, valid innocence claims are not limited to the (probably rare) cases in which the government charged the wrong person; they include cases in which the defendant committed the criminal act, but did so under duress, in self-defense, or without the requisite intent. Such cases may not be the norm, but they are far from unknown. In short, this pooling phenomenon may affect a substantial number of cases. Needless to say, they are the cases that raise the strongest concerns about faimess and accuracy.

To put it differently, the theoretical argument suggests that separating the innocent from the guilty-the central task of the system - takes place primarily at two stages: precharging and trial. Those innocent defendants who are not screened out at the first stage may be forced to wait for the last; plea bargaining, the intermediate stage, will afford them little relief. That is so because the prosecutor's incentive is to offer an innocent defendant the same deal that she would offer a guilty defendant with the same case file-with no downward innocence adjustment. This strategy permits the prosecutor to maximize net sentences over the population of defendants by capturing all the available rents from those defendants who are guilty. No doubt some percentage of innocent defendants who would have accepted a low-price offer will refuse the deal and win acquittals after a trial. These losses, however, are likely to be less than the losses to the prosecutor from underpricing the plea to the much greater number of factually guilty defendants. Since the prosecutor must bear one set of losses or the other, she is likely to choose the cheaper alternative and pool her risks.

From a defendant's perspective, the picture is similarly troubling. Bargaining defendants are, in effect, purchasing insurance from prosecutors, insurance against the risk of conviction and a high post-trial sentence. The pool of defendants includes high-cost insureds (guilty defendants whose conviction is extremely likely) and low-cost insureds (including innocent defendants whose conviction is much less likely). But the latter cannot effectively separate themselves from the former. They therefore must either buy the high-cost

128. The theoretical argument for those guilty of lesser offenses differs in one respect from the pure innocence cases: if the defendant is guilty of something and so signals to the prosecutor, any reputational benefits that may accrue from a clean record are dissipated. Thus, defendants who are guilty, but of lesser offenses than those charged, may suffer the greatest disadvantage from the pooling phenomenon. 
insurance or else self-insure by going to trial. Because of risk aversion, many of them will likely buy the insurance notwithstanding its high price, leading to a misallocation of criminal punishment.

The structural dynamic of plea bargaining leads, then, to a single variable contract in which all defendants-whether guilty or innocent-are offered a sentence based upon the prosecutor's estimate of the strength of the case at the time of bargaining plus the expected savings in transaction costs from shifting prosecutorial efforts to pleas rather than trials. Our analysis suggests that such a contract is inefficient because it fails to exploit the risk reduction potential of defendants' private knowledge. But the inefficiency is actually worse than it may appear. Innocent defendants are probably highly risk averse relative to guilty defendants. And the high cost of adjudication, coupled with its disproportionate allocation to the government, means that the gap between post-trial and bargained-for sentences will be greater than ordinary discounting might suggest. In other words, due in part to adjudication costs, the risk from going to trial is likely to be substantial, not because the probabilities of conviction are altered, but because the impact of conviction is so great. ${ }^{129}$ Risk averse defendants, meaning in part innocent ones, might well avoid that risk even at the cost of accepting a deal that treats them as if they were certain to be convicted at trial. ${ }^{130}$

Of course, this may not be much of a problem for the innocent defendant with a clean record who is charged with a very low-level crime. The likely post-trial sentence for such a defendant is minimal, so the plea offer will likely be quite favorable. ${ }^{131}$ But many crimes for which innocents might be charged are not so minor. A mail fraud or insider trading defendant may not have had the requisite intent, though the preliminary evidence may not convey that fact. Because such crimes are often committed by people with clean records, ${ }^{132}$ the absence of a bad record will not itself signal innocence. The same is true in murder prosecutions. The high acquittal rate in homicide cases-about thirty percent, almost double the rate for felony cases generally ${ }^{133}$-might suggest, among other things, that an unusually high number of innocents are charged with murder. ${ }^{134}$ This inference makes some intuitive sense, since the crime

129. The risk is a function of two factors: the probability of the result times its impact. Relative to the plea, the argument here is that the impact of conviction is greater for $D$ because the post-trial sentence will reflect adjudication costs that could have been saved by bargaining. In other words, the effect of adjudication costs is to increase the variance of the risk, and thus to visit it on risk averse parties.

130. See Grossman \& Katz, supra note 100 , at $755-56$ (where innocent defendants are more risk averse than guilty ones, plea bargaining is not effective separation device).

131. To put it another way, the prosecutor's incentive to "push" such cases is slight since the post-trial punishment will be so low. Consequently, favorable offers to defendants will carry little cost to prosecutors.

132. DAVID WeISBURD ET AL., CRIMES OF THE MIDDLE ClASSES 66-67 \& tbl. 3.4 (1991) (white-collar criminals are approximately half as likely as other criminals to have prior arrests or convictions).

133. See 1990 SOURCEBOOK, supra note 1 , at 526 tbl. 5.51 .

134. The reasoning is as follows: if acquittal is correlated (albeit not perfectly) with innocence, and there is an unusually high percentage of acquittals in murder cases, then there may be an unusually high number of innocent defendants on trial for murder. Since risk aversion should lead many (perhaps most) 
is one that is often committed by people who are not career criminals ${ }^{135}$ (hence, a generally law-abiding life will not convincingly signal innocence if the circumstances suggest otherwise), and the victim, by definition, cannot describe what happened. Such defendants cannot, at the plea stage, signal their higher likelihood of acquittal; they must take the same contract offered to guilty (and more-likely-to-be-convicted) defendants. Adjudication costs, together with simple discounting, produce a contract with a substantial sentencing gap. And a risk averse innocent defendant may be more likely to take the deal than a guilty one because for the innocent, bearing the risk of the higher post-trial sentence is more costly.

\section{The InNocence Problem and Plea Bargaining Doctrine}

Bargain theory helps identify what we believe to be the most problematic feature of plea bargaining: the dynamic of the parties' interaction makes it harder for innocent defendants to identify themselves. The normative question is what ought to be done about that problem at the level of legal doctrine.

The contemporary debate over plea bargaining has tended to push toward one of two polar alternatives for resolving real or perceived problems with the system. The first option, and the one implicitly adopted by current participants in the process, is to maintain the status quo. That is, the system might simply tolerate the innocence problem. The structural dynamic of plea bargaining may disadvantage innocent defendants, but most defendants are not innocent. (And even some innocent defendants are unaffected by the structural problem, since they can effectively signal their innocence in police interrogation, or by pointing to evidence that corroborates their claim at $T_{1}$.) Thus, the problem discussed above does not infect most bargains. In the typical case, the gains from trade are straightforward—savings in adjudication costs—and the bargaining dynamic is relatively uncomplicated. The prosecutor's reservation price reflects the fact that adjudication costs fall most heavily on the government. This in turn lowers the price of pleas, which makes pleas a good deal for guilty defendants. For all the reasons discussed in Part I, these typical cases appear to be paradigmatic value-enhancing bargains of the sort that the system ought to enforce. Moreover, innocent defendants still have the trial process to fall back on. This argument for the status quo is normatively plausible, however, only if the

innocent defendants to plead guilty, even given a substantial acquittal rate, the pool of all murder defendants probably includes an unusually high number of innocents.

Of course, there are other variables that help explain the phenomenon: juries may be particularly loath to convict in close cases where the penalties are likely to be steep, and proof of guilt is particularly hard for the government where (as is usually the case in homicide prosecutions) there are no witnesses and the evidence is circumstantial. Our point is only that innocent defendants are probably a substantial factor in the acquittal statistics, not that they are the only factor.

135. See RICHARD N. HARRIS, VIOLENT CRMME IN VIRGINIA 30 tbl. 12 (1989) (showing that $29 \%$ of convicted murderers had no prior record). 
problem is intractable. If there are feasible ways of improving the ability of innocents to separate themselves from guilty defendants, the system should adopt them.

The alternative that most legal academics appear to support is to abolish plea bargaining altogether. If the innocence problem is sufficiently great, it might justify abandoning the system of consensual allocation. After all, in other respects the rules of the game are stacked in favor of innocent defendants-the "beyond a reasonable doubt" standard of proof is the most obvious example, though far from the only one. Perhaps the same should be true here: if plea bargaining makes innocent defendants worse off, it should be eliminated.

Unfortunately, abolition would likely only worsen innocent defendants' plight. In order to accommodate the dramatic increase in trials, the trial process itself would have to be truncated, as Stephen Schulhofer's famous discussion of the Philadelphia process shows. The mini-trials that took the place of bargaining in Philadelphia were brief affairs, most lasting no more than an hour; the pretrial preparation on both sides was minimal. ${ }^{136}$ Altering the trial process in this way necessarily increases the error rate (unless our current trial system is nonsensical), meaning that it raises the rate at which innocent defendants are convicted. That, in turn, alters prosecutors' incentives when making decisions about which cases to take to trial. Indeed, it may alter police incentives when making arrests. Police officers and prosecutors alike can afford to be less careful in screening their cases if the trial "backstop" becomes more casual.

In short, prohibiting plea bargaining would likely raise the proportion of innocents who are convicted of crimes. The problem of defendants' inability to use their private information in bargaining would disappear since bargaining would disappear. But if the trial process itself led to a substantially higher rate of conviction of innocent defendants, the ex ante position of those defendants would not improve.

There is a third possible solution, however, one that the contemporary discussion largely ignores. ${ }^{137} \mathrm{~A}$ developed body of law defines and regulates plea bargains. That law might be adjusted in ways that (if only at the margin) facilitate the separation of innocent defendants from guilty ones at the bargaining stage. This approach depends, necessarily, on an understanding of how particular rules affect the bargaining dynamic between prosecutors and defendants. Conventional constitutional analysis, of the sort that dominates the plea bargaining literature, cannot provide such an understanding. But contract reasoning can. The same analytic tools that suggest the normative acceptability

136. See Schulhofer, Plea Bargaining, supra note 4, at 1055-57.

137. For a notable exception to the pattern in the literature of ignoring incremental reform, see McCoy \& Mirra, supra note 21, at $926-41$ (suggesting, inter alia, elimination of habitual criminal statutes, limitations on size of disparity between post-trial and post-plea sentences, and various mandatory information transfers to defendants). 
of plea bargaining as a general matter and also suggest the difficulty the bargaining dynamic creates for innocent defendants can help to identify possible legal moves to reduce that difficulty.

\section{A. First-Best Solutions}

Obviously, the best reform would be one that attacks the innocence separation problem directly. The problem arises from two facts: innocence claims are not readily testable, and trials are expensive. Because of the first fact, guilty defendants will try to copy any signal by which innocent defendants seek to identify themselves. Prosecutors must therefore offer the innocent the same deal as the guilty. Because of the second fact, that deal will include a high price for going to trial.

Any direct solution must change one of these two conditions. But such changes have enormous costs of their own. Consider the inability to test innocence claims at acceptable cost. That problem is, to a substantial degree, a function of lawyers' participation in the process, ${ }^{138}$ together with the bar on compelled questioning of defendants. ${ }^{139}$ Lawyers permit defendants both to refine their stories and to avoid traps. ${ }^{140}$ And the privilege against selfincrimination allows defendants to communicate with the government solely through counsel. These two basic entitlements combine to make it far easier for guilty defendants to plausibly claim innocence, or at least partial innocence. The government's eagerness to question defendants before they meet with their lawyers demonstrates the truth of this proposition. The virtue of such questioning is precisely that defendants' stories are less likely to have been carefully planned, and hence slip-ups (plus simple surrenders) are more easily induced. ${ }^{141}$ This effect is particularly strong if the police are allowed to use deceptive interrogation tactics of the sort that might trick guilty defendants into incriminating themselves. ${ }^{142}$

Getting rid of lawyers at the plea bargaining stage would thus help innocent defendants separate themselves, since their claims of innocence would be somewhat harder to copy. But eliminating lawyers would also (obviously) introduce the potential for sharp practices by the government. Defendants do

138. The Sixth Amendment gives defendants a right to counsel at all "critical stages" of the process, beginning with the initiation of formal adversary proceedings. Gilbert v. Califomia, 388 U.S. 263 (1967); United States v. Wade, 388 U.S. 218 (1967). The standards that apply to waiver of counsel ensure that, as a practical matter, lawyers will virtually always be a part of the plea negotiation process. See Stuntz, supra note 23 , at $826-27 \& \mathrm{nn} .186-87$.

139. Technically, that bar dates at least to Brown v. Mississippi, 297 U.S. 278 (1936), which held that the admission into evidence of involuntary confessions violates due process. As a practical matter, it has existed only since Miranda v. Arizona, 384 U.S. 436 (1966).

140. This is, in a sense, the theme of Kenneth Mann's insightful book on the defense of white-collar crime. See MANN, supra note 116.

141. This is the only plausible explanation for the fact that, even after Miranda, the police continue to obtain confessions in a large number of cases.

142. For an explanation and defense of such tactics, see Stuntz, supra note 23, at 805-18, 822-25. 
not know what legal claims they might have; they might therefore fall prey to bargains that fail to account for legally valid defenses or entitlements to suppress certain types of evidence. ${ }^{143}$ The argument in Part I-that plea bargaining does not raise serious duress or unconscionability concerns-depends, to a substantial degree, on the ability of defense counsel to prevent government overreaching. Were defense counsel absent, the picture would change in ways that might hurt innocent defendants most of all.

For reasons we have already discussed, the same is true of the trial process. That process is costly, in large part because of the many rules designed to maximize innocent defendants' chances of acquittal. If the process is cheapened, the error rate will rise, and prosecutors' selection of cases at the charging stage will change accordingly. There is no reason to think such changes would make innocent defendants as a whole better off.

\section{B. Second-Best Solutions}

Even though reform cannot eliminate the basic problem, it can help innocent defendants by increasing prosecutors' incentive to take account of the odds of acquittal apart from defendants' private information. This is no small point. Some (perhaps many) innocent defendants are unaffected by the bargaining dynamic described in Part II, because they have important information corroborating their innocence claim at $T_{1}$, information that should lead both sides to discount the odds of conviction substantially. The law can best protect these defendants by ensuring that this information is factored into the price of the bargain. More to the point, defendants who are harmed by the pooling phenomenon will often have some corroborating information at $T_{1}$ : just as innocence is correlated with favorable yet-to-be-discovered evidence, it is also correlated with favorable evidence already known to the parties. At $T_{1}$, many defendants may appear, say, sixty-percent likely to be convicted should the case go to trial. Most of these defendants are guilty. But some are not, and for the reasons set forth in Part II, they will find it hard to distinguish themselves from their guilty counterparts. The discussion thus far suggests that the law may find it impossible to eliminate that problem. But it may nevertheless be able to improve these defendants' welfare by ensuring that "sixty-percent cases" are priced differently than "ninety-percent cases."

Of course, prosecutors already have an incentive to price cases according to expected outcomes, based on the information available to them at the time of bargaining. But current law inexplicably dilutes that incentive in a number of ways, encouraging prosecutors to treat close cases the same as clear ones, and thereby harming innocent defendants unnecessarily. We have selected three

143. See id. at 830-31 (explaining why rules governing waiver of counsel are so much more stringent at plea stage than at interrogation stage). 
such areas-the rules governing enforceability, mistake, and the fixing of posttrial sentences. In each, the law makes the problem of separating innocent from guilty worse than it need be; in each instance, we suggest a fairly simple reform that would ameliorate the problem.

The argument turns on the interaction between the legal rules and the bargaining dynamic. Contract law is largely designed to facilitate fair and efficient bargains. Unsurprisingly, then, looking to appropriate contract analogies turns out to be enormously helpful in identifying opportunities for productive change in the doctrine.

\section{Enforceability}

When defendants promise to plead guilty in return for government concessions and then do so, they are legally entitled to the concessions. ${ }^{144}$ At the same time, if the defendant fails to perform, the prosecutor need not perform either. ${ }^{145}$ But while the exchange of promises is, to this extent, supported by legal sanctions, plea bargains are not enforced according to standard, gardenvariety contract principles of offer and acceptance. As a consequence, defendants' ability to rely on government promises is much lower than in comparable private settings.

The problem stems from two legal rules. The first holds that the bargain is ordinarily not binding until the defendant actually pleads guilty. Thus, if the prosecutor promises to recommend a ten-year sentence in exchange for a plea, and the defendant agrees, either the prosecutor or the defendant may still cancel the deal at any time prior to the defendant's performance. ${ }^{146}$ The second rule is related to the first: prosecutors may not bind judges. A prosecutor can promise to recommend a given sentence (or sentencing range), but she cannot guarantee that the defendant will actually receive that sentence. ${ }^{147}$ The judge ${ }^{148}$ alone decides the defendant's sentence, save for cases in which a legislatively mandated sentence exists. ${ }^{149}$ The most that can be done is to condition the defendant's plea on the receipt of a particular sentence (meaning that if the judge rejects the prosecutor's recommendation the plea is rescind-

144. Santobello v. New York, 404 U.S. 257 (1971). For the best discussion in the literature of what this entitlement might mean in practice, see Peter Westen \& David Westin, A Constitutional Law of Remedies for Broken Plea Bargains, 66 CAL. L. REV. 471 (1978).

145. Mabry Y. Johnson, 467 U.S. 504 (1984).

146. Id.; see also 2 LAFAVE \& ISRAEL, supra note $100, \S 20.2(\mathrm{e})$ (1984 \& Supp. 1991). The only exception is in cases where the defendant acted to his substantial detriment in reliance on the prosecutor's promise. See supra note 69 and accompanying text.

147. See, e.g., FED. R. CRM. P. 11(e) (permitting prosecutor to issue either of two types of nonbinding sentence recommendations, one that can be revised by court without notice to the defendant, and one that can be revised only after giving defendant the opportunity to rescind his plea).

148. In some jurisdictions, juries decide sentences. However, judicial sentencing remains the norm.

149. To put it another way, the prosecutor is given essentially total discretion to define the charge, but the judge (acting ex post) and legislature (acting ex ante) determine the sentence. 
ed), ${ }^{150}$ and this practice is discouraged or prohibited in many jurisdictions. ${ }^{151}$ The typical plea bargain is in fact an agreement by both sides to present the case to the sentencing judge in a particular way-from the defendant's side, an agreement to plead guilty to specified offenses; from the government's side, a promise to say (or to avoid saying) particular things at sentencing. But the agreement is curiously one-sided: the defendant's plea is ordinarily binding, while the prosecutor's words constitute mere advice that the court can accept or ignore as it wishes.

Note the effect these rules have on innocent defendants. The current regime basically invites judges to revise bargained-for sentencing recommendations upward when recommended sentences seem unusually low. Yet if the prosecutor and defense counsel agree to recommend an unusually low sentence, that recommendation may reflect the parties' estimation of the probability of conviction (and perhaps the possibility of the defendant's innocence) should the case proceed to trial. ${ }^{152}$ The prosecutor and defense attorney have far better information about the probability of conviction than the judge, whose knowledge of the case is limited to the papers the parties filed with the court. Moreover, the prosecutor has an incentive not to disclose such concerns to the judge, since the prosecutor does not wish to cast doubt on her own case before the person who may try it should the bargain break down. The existing rules thus make it harder for the parties to internalize any information that suggests the possibility of the defendant's innocence-not simply the defendant's private information. The judge who overturns bargains that seem too favorable to the defense risks punishing precisely those defendants who least deserve it, and precisely those who are victimized by the structural problem discussed in Part II.

This effect stems from the failure to treat the prosecutor as a genuine party to the plea bargain. The current regime treats the prosecutor's promise (even if formalized) not as an "offer" that the defendant may "accept" and then enforce, but as an invitation to negotiate, with the deal sealed only when the parties go to court. ${ }^{153}$ The prosecutor's proposal, even if accepted, typically does not define the price of the defendant's offense-the only obligation is that the prosecutor mouth the right words at sentencing. The judge sets the price. To put it differently, in contract terms the bargain is not really between the

150. See, e.g., FED. R. CRIM. P. 11(e)(4).

151. See Alschuler, Trial Judge's Role, supra note 4, at 1070-72 \& nn. 42, 45.

152. In Part II, we argued that bargains often will not reflect this probability. Our point here is only that (1) they sometimes will, and (2) those occasions are likely to be particular targets for judicial upward revision. Moreover, prosecutors will take account of objective information available to the government at the time of negotiations, even though they will not ordinarily irvest substantial effort in verifying defendants' claims. And in some cases, the objective evidence will raise some doubt about the defendant's guilt. These cases too are obvious candidates for low-probability-of-conviction pricing, and hence also candidates for judicial upward revision.

153. Formally, the judge's approval is a condition precedent to the bargain. See Jones, supra note 12, at $611,613-14$. 
defendant and the prosecutor, since the prosecutor can make only token commitments. The true contracting parties are the defendant and the judge. The prosecutor acts as the judge's negotiating agent, but the judge retains the authority to accept or reject his agent's work. ${ }^{154}$

This principal-agent model is useful in some contract settings, but it has several fundamental problems in the plea bargaining context. Most obviously, the prosecutor better understands the details of the particular negotiation than the judge-that is, the prosecutor is much better positioned to know the odds of acquittal, and hence to know whether a low-probability price is justified. Moreover, the judge has a far poorer understanding of the opportunity cost of going to trial than does his "agent," the prosecutor. In private settings, the whole point of retaining final authority in the hands of the principal, even while using an agent to negotiate the deal, is that the principal knows more than the agent about alternative investments the firm might pursue if this deal is not made. But in the plea bargaining setting, the party who knows the opportunity cost of a bargaining breakdown is the prosecutor, not the judge. Whether the bargain is a good one depends, in large part, on what the prosecutor (more generally, the district attorney's office) can accomplish with the time saved by avoiding a trial. That, in turn, depends on the range of arrests that are brought to the office for prosecution, since those arrests define the prosecutor's options. The prosecutor knows a good deal about this choice set; the judge knows little or nothing. ${ }^{155}$

The only reason for not allowing the prosecutor to set the maximum sentence as part of the plea bargain is that the prosecutor may sometimes undervalue society's interest in punishing serious offenders. The premise that judges are better than prosecutors at internalizing social interests in deterrence and retribution seems to us implausible on its face. ${ }^{156}$ But even if our intuition were false, the fact remains that prosecutors make binding decisions not to pursue criminal punishment at all, and judges have no power to review such

154. Note too that the agent's negotiating authority is quite circumscribed. The defendant typically must decide whether to plead guilty before the judge announces his sentence; that is, the principal in this threecornered bargain has the authority to set a price within a wide range, and the defendant agrees to plead subject to that authority. See 2 LAFAVE \& ISRAEL, supra note $100, \S 20.4(\mathrm{~g})$, at 656 \& $\mathrm{n} .137$.

155. The mandatory nature of the plea bargaining rule makes this problem worse: the prosecutor cannot make binding sentencing arrangements even if both she and the defendant wish to do so. This leads to costly adaptive behavior on the part of plea bargaining participants. In some jurisdictions, for example, judges become active participants in the bargaining process, either by signaling what sentences they will and will not accept, or by dealing directly with defense counsel, thereby substituting their own bargaining for that of their prosecutorial "agents." JONES, supra note 9, at 102-04, 202; Alschuler, Trial Judge's Role, supra note 4, at 1087-99. There is a sense in which this behavior is efficient, given the existing rule structure: it reduces the risk that proposed bargains will be later rejected, and thereby promotes reliance on prosecutors' sentencing promises. But it plainly adds to the transaction costs of plea bargaining. And it may have other undesirable consequences as well-for example, by becoming a participant in the bargaining process, judges may lose their air of objectivity, an effect that, if sufficiently pervasive, might undermine faith in the trial system.

156. We argue below that judges may better internalize defendants' interests; thus it may be desirable to limit the prosecutor's ability to bind the government to minimum sentences. 
decisions. ${ }^{157}$ In other words, if the prosecutor is, relative to the judge, a poor agent for the public interest in law enforcement, ${ }^{158}$ the proper response is a system of judicial review of charging decisions (including decisions not to charge). Absent such a regime, it seems odd to bar the prosecutor from fixing a ceiling on the permissible sentence.

Moreover, if guarding against excessively low prosecutorial sentencing offers is the reason for the nonenforcement rule, the rule may well be counterproductive. Under the current regime, defendants who plea bargain must bear the risk that the judge will not follow the prosecutor's recommendation. That risk cannot be cost free; the resulting contract price is more favorable to defendants in order to compensate for the risk that the deal will be upset at sentencing. This means prosecutors presumably recommend lower sentences due to the rule that allows their recommendations to be overturned. This result magnifies the disparity between the judge's view of the proper sentence and the prosecutor's recommendation. That is, the rule that allows the judge to overturn overly light sentencing recommendations tends to foster even lighter sentencing recommendations. And given that innocent defendants are more likely to be risk averse than guilty ones, the greater disparity between trial sentences and plea sentences can only aggravate the innocence problem. Enforcing prosecutors' sentencing promises would thus reduce (1) uncertainty, (2) transaction costs, ${ }^{159}$ and (3) the disparity between post-plea and post-trial sentences.

These changes would plainly make innocent defendants better off. Current$1 y$, if a prosecutor recommends a given sentence in a given case, the judge may either accept the recommendation or ignore it and give the defendant something much worse. Moreover, the innocent defendant may refuse to deal and go to

157. See, e.g., Inmates of Attica Correctional Facility v. Rockefeller, 477 F.2d 375 (2d Cir. 1973); Easterbrook, supra note 36, at 299.

158. See Schulhofer, Criminal Justice Discretion, supra note 4, for the most well-developed argument that this is the case.

159. There is a related advantage to enforcing prosecutors' sentencing promises: doing so would eliminate a large number of disputes over alleged government breach. It is common for defendants to claim, after receiving a sentence higher than the one the prosecutor agreed to recommend, that the prosecutor did not make her recommendation with sufficient force, or that she undermined it in some way. Naturally, the defendant sees such behavior as a breach. In subsequent litigation, courts must determine just what a promise to recommend a given sentence requires-a determination that is necessarily uncertain. See 2 LAFAVE \& ISRAEL, supra note $100, \S 20.2$ (d), at 588-94. Moreover, the court upon finding a breach must decide what remedy is appropriate. See Westen \& Westin, supra note 144. There is no good answer to this remedial problem. If the court orders specific performance-i.e., resentencing following a proper recommendation by the government - the sentencing judge will necessarily be aware that the government was unenthusiastic about its recommendation. Alternatively, rescinding the defendant's plea, the other possible remedy, may be tantamount to acquittal, and hence may overcompensate for the breach.

These difficulties do not arise in cases where the prosecutor's promise is binding. There may be ambiguous cases where it is unclear whether the prosecutor meant to offer a binding sentence or only a recommendation, but workable default rules should make that line fairly easy to draw. And the remedial issue disappears: if the prosecutor promised a five-year sentence, the defendant can get no more than the five-year sentence. Sensible doctrine on enforceability would, in other words, simplify the doctrine on remedies as well. 
trial, where (if convicted) his sentence will be worse still. Enforcing prosecutors' promises would eliminate the second of these options, and thereby reduce the incidence of the third (by making prosecutors' promises more reliable). Guilty defendants might benefit from enforcement as well, given the reduction in transaction costs. But the biggest winners would be the innocent.

\section{Mistake}

In all bargains, there is a risk that one party or the other may foolishly agree to terms that do not promote self-interest. This risk affects guilty and innocent defendants alike, but it disproportionately afflicts the innocent. If the defendant is innocent, the probability of conviction must be substantially less than one hundred percent, a fact that the price of the plea bargain ought to take into account. But risk averse innocent defendants may accept bargains that treat them not merely as probably guilty, but as certain to be convicted. Thus, when an innocent defendant's lawyer erroneously prices her client's case, and negotiates a deal that presumes certain conviction, there is a good chance the bad deal will be accepted. In short, mistakes in bargaining surely affect the whole system, but are particularly likely to determine outcomes in cases where guilt is in some question.

Contract law addresses the risk of mistake in two different ways. In the occasional case in which a material mistake by one side either was or plainly should have been known to the other side, the contract is voidable at the instance of the mistaken party. ${ }^{160}$ In the mass of disputes, the mistaken party bears the risk of his own errors-with one important twist. If the mistake was an attorney's, the mistaken party can sue for legal malpractice, with the possibility of a damage recovery if the lawyer's error was causally related to the loss.

Plea bargaining doctrine largely duplicates the first of these rules, but not the second. Either party can void the bargain if the other engaged in misrepresentation or its functional equivalent. ${ }^{161}$ In addition, the defendant is permitted to rescind his plea if he can show that (1) his lawyer was constitutionally ineffective, and (2) but for the lawyer's errors he would not have pled

160. It is worth emphasizing that this rule applies only in the unusual case; ordinarily, a mistake by one party will not preclude enforcement of the contract. See, e.g., Anderson Bros. Corp. v. O'Meara, 306 F.2d 672 (5th Cir. 1962); RESTATEMENT (SECOND) OF CONTRACTS $\$ \S 153-154$ (1988).

In cases where the relevant information was gathered through what one might call protected investment, there is no duty to disclose. See Laidlaw v. Organ, 15 U.S. (2 Wheat.) 178 (1817); Anthony T. Kronman, Mistake, Disclosure, Information, and the Law of Contracts, 7 J. LEGAL STUD. 1 (1978). The familiar example is the geologist who buys land from a famer knowing that there is oil under the land; the geologist need not disclose this information to the farmer even though he knows the farmer believes the land contains nothing of value. Cf. Saul Levmore, Securities and Secrets: Insider Trading and the Law of Contracts, 68 VA. L. REV. 117, 137-42 (1982) (arguing that in such cases, the geologist should perhaps be allowed actively to deceive the farmer).

161. See 2 LAFAVE \& ISRAEL, supra note $100, \S 20.2$ (d), at 587-602. 
guilty. ${ }^{162}$ In practice, only truly atrocious lawyering leads to a judicial finding of ineffective assistance in the guilty plea setting. ${ }^{163}$ This is unsurprising, since the governing Supreme Court decision states that relief is appropriate not where the defendant might have struck a better deal, but only where he would not have pled guilty at all. ${ }^{164}$ Because most attorney error affects the price of the plea rather than its existence, most attorney error does not amount to ineffective assistance. In short, aside from occasional instances of incredible incompetence, it is not so much defense attorney error as government advantage-taking that determines whether a defendant can rescind his plea based on mistake.

One might suppose that this regime makes good sense for the same reasons that justify the contract doctrine on unilateral mistake. But there are structural asymmetries in the plea bargaining context that are missing in the ordinary contract setting. If a contracting party makes a bad deal because of an error by his lawyer, he may not be able to void the contract, but he can sue the lawyer. This provides valuable insurance against the kinds of bargaining errors that lawyers might make. Criminal defendants who plea bargain have no such option, not because the law forbids them to sue, but because guilty criminals who think they should have gotten lighter sentences are paradigmatically unsympathetic plaintiffs. That deficiency is compounded by another difference between plea bargaining and other settings where lawyers bargain on behalf of their clients: the defense attorney in a plea bargaining setting has a substantially lower market incentive to bargain well. A large proportion of criminal defense counsel are court-appointed (indeed, many work for a public defender's office); their future business does not depend on successful haggling with prosecutors. Moreover, such attorneys are paid according to a fixed schedule, so that good bargaining will not necessarily lead to higher fees. Of course, this is not true of privately paid defense counsel. But even for them, the absence of an effective malpractice option removes some incentive to avoid lazy or otherwise deficient bargaining.

162. Hill v. Lockhart, 474 U.S. 52 (1985).

163. See Gary Goodpaster, The Adversary System, Advocacy, and Effective Assistance of Counsel in Criminal Cases, 14 N.Y.U. REV. L. \& SOC. CHANGE 59, 80-83 (1986). There is one possible exception to this statement. Some cases indicate that relief is available where defense counsel's error was partly the government's fault. In Ex parte Pool, 738 S.W.2d 285 (Tex. Crim. App. 1987), for example, the prosecutor told defense counsel that the defendant was eligible for habitual offender treatment based on the timing of his past convictions; defense counsel accepted the prosecutor's statement as factually true, and accordingly advised his client to accept the state's proposed bargain and plead guilty rather than face sentencing as an habitual offender. Id. at 286 . The prosecutor's statement was wrong, and the court found the defense counsel constitutionally ineffective and awarded relief. $I d$. Though cast as an ineffective assistance decision, Pool actually seems more like a commonsense application of unilateral mistake doctrine: the govemment could easily have prevented the defendant's error (indeed, the government induced it), and the defendant was accordingly excused from his bargain.

164. Hill v. Lockhart, 474 U.S. at 59 ('Mnn order to satisfy the 'prejudice' requirement [of ineffective assistance doctrine], the defendant must show that there is a reasonable probability that, but for counsel's errors, he would not have pleaded guilty and would have insisted on going to trial."). 
The absence of a credible malpractice threat, coupled with the way criminal defense lawyers are hired and paid, surely raises the risk of attorney error in bargaining. And it is hard for criminal defendants to take precautions against such errors, harder than for most contracting parties. In the plea bargaining setting, the difference between a good and bad deal depends on (1) knowledge of likely trial outcomes, including the behavior of judges exercising their sentencing discretion, and (2) a good sense of the going "market price" of the relevant category of crime-i.e., the sentence usually assigned after a guilty plea in similar cases. Defense lawyers are well positioned to have both kinds of information. Criminal defendants are not-especially defendants who have little prior exposure to the system, which includes those defendants who are likeliest to be innocent.

All this argues for a more generous mistake or excuse rule in plea bargaining (on the defendant's side) than in ordinary contract cases. But regulating mistake directly is hard, if not impossible. The problem is that one cannot distinguish between good and bad bargaining by looking at the process by which the lawyers reached their deal. A two-minute conversation with the prosecutor in the hallway with only slight advance preparation may represent evidence of sloppiness and sloth. Or it may be that defense counsel, who has a great deal of experience in dealing with similar cases, knows the market price, realizes that investigation is extremely unlikely to lead anywhere, and understands how to get to the best offer expeditiously. ${ }^{165}$ In a context where bargaining skill depends more on knowledge of information about other cases than on case-specific preparation, it is hard to judge a defense attorney's performance by his behavior in any one case. ${ }^{166}$

The only feasible alternative is to review not process but outcomes. A bargained-for sentence that substantially exceeds the norm for the crime is probably due to some kind of defense attorney mistake; at the least, the bargain requires some explaining. The judge is in a poor position to supervise the bargaining process, but he is in a very good position to recognize unusually high sentences. This is particularly true if high sentence recommendations are caused by problems of information revelation that cause defendants' claims of factual innocence to be discounted. Defense attorney mistakes and the inno-

165. This is consistent with Heumann's finding that novice defense attomeys over-bargain and are to some degree punished for doing so by prosecutors and judges. HEUMANN, supra note 5, at 67-69.

166. Note how different plea bargaining is in this respect from trial. When deciding whether a lawyer did a good job in a given trial, it is possible to look solely at what the lawyer did in that case-how he prepared, which witnesses he called, how he argued to the jury, and so forth. When deciding whether a plea bargain was well done or not, however, one would learn little from a transcript of the prosecutor-defense attorney conversation. Instead, a sensible evaluation would require a great deal of other information, not about the case at hand, but about other cases. This may be why ineffective assistance doctrine, which was plainly fashioned with trials in mind, has not proved particularly useful in the plea setting.

For arguments that ineffective assistance doctrine has indeed failed in this setting, see Albert W. Alschuler, Personal Failure, Institutional Failure, and the Sixth Amendment, 14 N.Y.U. REV. L. \& SoC. CHANGE 149, 154-55 (1986); Schulhofer, supra note 10, at 141-42. 
cence problem both argue for treating a bargained-for sentence as a ceiling, but not a floor. Downward judicial revision should be, and generally is, available at the judge's discretion. But the law should go further: downward discretion should be encouraged whenever the sentence is substantially above the "market level" in the relevant jurisdiction.

Aggressive downward revision does have a problem: it adds to the transaction costs of bargaining. As with defendants and upward revision, a prosecutor must be compensated for bearing the risk that the judge will throw out her deal; also as with defendants, the obvious means of compensation is to alter the price term of the bargain. Thus, discretionary downward revision would raise the overall level of bargained-for sentences, and would reduce the total number of bargains. But these effects should be much more limited than the seemingly analogous effects of allowing upward revision. Notwithstanding defendants' preference for risk taking, the prosecutor is probably less risk averse than the defendant: because she has a portfolio of cases (and also, obviously, because she does not personally serve the time), the prosecutor cares less about the possibility that a given sentence will be reduced from ten years to five than the defendant cares about it being raised from five years to ten. To put it differently, a wide variance in outcome in a particular case is less important to the prosecutor because (unlike the defendant) it is the expected value of plea bargains generally that determines her returns on bargaining. This means that a dispersion of outcomes on the prosecutor's side of the bargain is not likely to lead prosecutors to refuse to bargain altogether.

\section{Background Prices and Duress}

The scenario that most troubles critics of plea bargaining is the innocent defendant who faces a life sentence if convicted at trial and is offered a plea bargain at a recommended sentence of a few years. The huge disparity between the post-trial sentence and the plea sentence presumably leads the defendant, though innocent, to accept the deal. Frank Easterbrook rightly points out that this story is not necessarily a condemnation of plea bargaining. The sentencing differential may simply reflect a low probability of conviction (based on evidence available to the government), or it may stem from limited prison space in the relevant jurisdiction. In either of those cases, the defendant is much better off with the offer than without it: a murder defendant who has a fifty-percent chance of winning at trial wants a regime that allows the prosecutor to offer 
a ten-year sentence with a plea. ${ }^{167}$ The situation is a sad one, but preventing the offer only makes it sadder.

The plea offer in such a case does not amount to duress. ${ }^{168}$ But there is a duress problem with large sentencing differentials in some types of cases, a problem that may disproportionately harm innocent defendants. The best way to get at the problem is to imagine an ordinary executory contract in which one party aims to convert an uncertain future outcome into a certain present onethe same thing criminal defendants do when they bargain with prosecutors. Suppose a buyer is trying to purchase a certain quantity of grain for delivery in one year. There are two possible courses of action if the buyer does not reach a deal with a particular seller. First, he can go to another seller. Second, he can wait until closer to delivery and buy the grain on the spot market. Both options act as a check on the seller: competitors prevent the seller from charging a monopoly price, and the existence of a spot market means that the seller's price is constrained by expectations about the market's future performance.

The first constraint is absent in plea bargaining: prosecutors do not compete for customers; ${ }^{169}$ rather, they take those cases assigned to them. ${ }^{170}$ Stephen Schulhofer has emphasized this prosecutorial monopoly, arguing that it creates a substantial potential for misbehavior. ${ }^{171}$ Yet the absence of prosecutorial competitors is not by itself a great problem because there is another check on the prosecutor's ability to behave strategically, one that is roughly analogous to the spot market. If the prosecutor wants to reach a bargain, she must offer the defendant something better than the expected value of going to trial, discounted for the defendant's risk aversion. ${ }^{172}$

The prosecutor is thus in an odd position: she resembles a seller of grain futures who has no direct competitors, but who must price her futures contracts against the backdrop of a working spot market whose price is not within the seller's control. If the outcomes generated by that market-here, trial verdicts and sentences-amount to sensible social policy, the prosecutor's bargaining behavior should be generally sensible as well, because those outcomes constrain

167. Easterbrook, supra note 36 , at 320 (noting the problem of innocent defendants who face strong government cases: "[i]t would do defendants no favor to prevent them from striking the best deals they could in such sorry circumstances"); Grossman \& Katz, supra note 100, at 749 (viewing plea bargaining as an insurance device for innocent defendants); Edward A. Ruttenberg, Plea Bargaining Analytically-The Nash Solution to the Landes Model, 7 AM. J. CRIM. LAW 323, 346-47 (1979) (arguing that innocent defendants are better off with bargaining option as long as trial error rates are positive).

168. See supra text accompanying notes $30-38$.

169. Though they do compete in other ways; that is, in a typical district attomey's office, a typical prosecutor is constrained somewhat by the efficiency and winning percentages of his colleagues.

170. If a given defendant is displeased with the offer that a prosecutor has given him, he cannot simply do business with another prosecutor, he is stuck with whomever the district attomey's office assigns to his case. The same is true, though in a slightly different sense, of the prosecutor: if the bargain breaks down she must either take the case to trial or let the defendant off; she cannot fob the case off on another prosecutor. The analogue for the grain seller would be a world in which she must either reach agreement with this particular buyer or give a certain amount of grain away.

171. Schulhofer, Criminal Justice Discretion, supra note 4, at 63-66.

172. For the best discussion of this tradeoff in the literature, see Easterbrook, supra note 36, at 311-17. 
the prosecutor's pricing decisions. It is also true, of course, that if post-trial sentences are too long or too short, post-plea sentences will be as well, since pleas are not competitively priced. Whether post-trial sentences are or are not sensible is a matter of sentencing policy. Our point is that the prosecutor's bargaining (and pricing) decisions are a function of that policy.

Despite the fact that defendants cannot switch prosecutors, then, the prosecutor's pricing decisions seem to be constrained, just as the monopolist futures seller is constrained by the spot market. But the constraint depends on the prosecutor's inability to manipulate post-trial sentences. At first blush, one might think such manipulation impossible. Prosecutors do not set post-trial sentences; judges or juries do, within rules set by legislatures. Thus, every trial arguably generates a sentence that represents a social judgment by disinterested decisionmakers (some combination of legislators, judge, and jury) about the optimal sentence for the relevant criminal episode. To the extent that plea bargaining takes place against the backdrop of those judgments, the argument goes, it really does look like the working spot market, efficiently constraining the prosecutor's pricing decisions.

Manipulation is possible, however, when the social judgment in question is categorical rather than individualized. The longstanding pattern of American substantive criminal law is overbroad definition of crimes coupled with broad prosecutorial and judicial discretion. That is, legislatures writing criminal codes tend to be much more concerned with capturing all the behavior that they wish to punish than with excluding all the behavior that they wish to leave alone. This practice creates not only broad criminal liability, but also overlapping crimes: a single episode may fall within the definition of several criminal offenses, ranging from trivial misdemeanors to serious felonies. Moreover, defendants can often be charged with more than one offense for what seems like a single act. The system has historically compensated for this overbreadth in two ways: (1) prosecutors have been given absolute discretion not to charge anyone with any given crime, and (2) judges traditionally have had the discretion to assign sentences within a very wide range. The second protection is critical. Without it - that is, in a world of fixed sentences that attach to particular charges-a prosecutor has the ability to determine not merely the charge, but the post-trial sentence as well. This allows the prosecutor to inflict severe punishment on defendants who, though their behavior may fit the terms of the relevant criminal statutes, do not really deserve it (meaning that no disinterested legislature or court would apply such punishment to those defendants in isolation). ${ }^{173}$

173. Note that in saying what defendants do and do not "deserve," we are not implicitly adopting any normative theory of a "just sentence." Rather, our point is essentially descriptive: that there are defendants who would receive $X$ years in prison if the legislature were to sentence those defendants individually, but would receive $X+Y$ years under a mandatory sentencing statute enacted by the same legislature. This gap-between the outcome under a politically responsive discretionary regime and a politically responsive mandatory regime-is what we refer to as the difference between what the individual defendant "deserves," 
This might not be much of a problem in a system that prohibits plea bargaining. Prosecutors do not, after all, gain much by successfully trying petty criminals for serious charges, personal score-settling aside. ${ }^{174}$ Thus, using fixed or mandatory sentences might create some potential for sporadic arbitrariness by prosecutors (no doubt a bad thing), but it would not generate any systematic distortions in the allocation of criminal punishment.

The picture is different, and more troubling, when plea bargaining is added to the equation. Consider, for example, the facts of Bordenkircher v. Hayes. ${ }^{175}$ Hayes was charged with uttering a forged check for $\$ 88.30$. He had two prior felony convictions, one for "detaining a female" (a sexual assault charge), the other for robbery. He served a total of five years on the two earlier charges, not counting probation time. Because of these two prior convictions, Hayes was eligible (though barely) to be charged under Kentucky's habitual criminal statute, which carried a mandatory sentence of life in prison. The prosecutor offered to let Hayes plead guilty to a lesser charge and to recommend a fiveyear sentence. If Hayes refused, he would be charged as a habitual criminal. Hayes refused the offer, and the prosecutor carried out his threat. ${ }^{176}$

Suppose that Hayes' earlier convictions were fairly low-level felonies, a possibility that would tend to explain the relatively light sentences he had received. Suppose further that Kentucky's habitual criminal law had authorized a sentence of anywhere from ten years to life. The judge's sentence for the forgery charge would surely have fallen closer to the minimum than the maximum. And that conclusion is consistent with the decision the legislature made when it passed the habitual criminal statute. Felonies encompass a wide range of criminal behavior; the legislature made, at best, a roughly accurate categorical judgment. If the same legislators who passed the statute were to vote on sentences case by case, many defendants who qualify for habitual criminal sentencing would get far less than life in prison. This might imply that the habitual criminal statute is irrationally overinclusive. The implication, however, is too simplistic; the key point is that the legislature did not intend for the statute to be applied to every offender who might fall within its terms. Rather, the legislature implicitly relied on prosecutors to separate the wheat from the chaff-to exercise their discretion not to pursue habitual criminal sentencing for offenders who fell within the statute but seemed not to deserve such harsh treatment. Bordenkircher may well be such a case; that is, the legislature may

\footnotetext{
in the view of the responsible decisionmakers, and what he gets.

174. Actually, prosecutors do get one other benefit: publicity. This is important where the individual being overpunished is generally thought by the public to be guilty of misconduct beyond the formal charges. See David Pritchard, Homicide and Bargain Justice: The Agenda-Setting Effect of Crime News on Prosecutors, 50 PUB. OPINION Q. 143 (1986).

175. 434 U.S. 357 (1978).

176. See id. at 359. The Kentucky statute provided for habitual criminal status for three felony convictions; Hayes' low-level forgery constituted the necessary third charge. Interestingly, sometime after Hayes' case was tried, Kentucky revised its statute to lower the sentence level and to reintroduce some judicial discretion. Id. at 359 n.2.
} 
have expected that prosecutors would not charge people like Hayes under the statute, though no enforcement mechanism backed up that expectation (because judicial review of charging decisions would be too costly).

The Kentucky statute thus gave the prosecutor a good deal of bargaining power over people like Hayes because it allowed him to threaten a sentence that, absent the statute, would have been implausible. ${ }^{177}$ The prosecutor did not employ this threat to raise the price of his offer, since he had no particular incentive to overpunish low-level repeat offenders. But he did have an incentive to increase the likelihood that his offer would be accepted-and that is how he framed his bargaining strategy. The huge sentencing differential in Bordenkircher suggests that while the prosecutor may have been charging something like a "market price" for the guilty plea, he was putting pressure on Hayes to take the deal without further dickering. In a discretionary system, the choice might have been between a recommended five-year sentence and a likely ten or twelve years if the case went to trial. Given the statute, the choice was much more stark: five years or life. Hayes might not have accepted that deal, but every future defendant is likely to do so and do so quickly.

The contract analogy is economic duress, the lone gas station in the middle of the desert that charges fifty dollars for a gallon of gas. Like the prosecutor in Bordenkircher, the gas station usually gets its asking price, because the difference between that price and the cost of going without (death in the desert) is so high. But contract law has resolutely rejected the buyer's duress argument in such cases, on the sensible theory that since the constraint on the buyer's choices (no gas in the desert) was not produced by the seller's actions, the buyer was better off with the offer than without it. ${ }^{178}$ Imagine, however, that the gas station owner goes further. Figuring that the buyer will kick and scream and haggle for an hour, but will eventually agree to the seller's price, the seller decides to cut the negotiation short by letting the air out of the buyer's tires and offering to refill the tires if, but only if, the buyer pays the seller's asking price for gas. The tactic may well be socially beneficial in a narrow sense. The cost of deflating and reinflating the tires may be less than the transaction costs that the gas station owner saved, and the owner may be right to conclude that the parties would have reached the same deal anyway. The problem is that we can never know whether that conclusion is correct, because the seller has removed any remaining market constraint on her pricing. She has reduced transaction costs only by artificially constraining the buyer's choice.

The same is true of the prosecutor in Bordenkircher. What he gets from threatening to invoke the habitual criminal statute is lower transaction costs: most defendants in Hayes' position will speedily accept the five-year offer once

177. This is a common use of habitual criminal statutes in other countries as well as this one. See JOHN F. KLEIN, LET'S MAKE A DEAL 101-04 (1976) (discussing how Canada's habitual criminal statute came to be "[t]he most potent of all bargaining levers" the government used in plea negotiations).

178. See supra text accompanying notes $34-38$. 
they realize that the prosecutor is not bluffing. That may be a good thing if the prosecutor's charging decisions are good ones. But the defendant's eagerness to bargain can change the nature of the charging decision. A prosecutor who knows that even a weak case will generate an easy plea (because of the defendant's fear of an overlong post-trial sentence) has little incentive to separate strong cases from weak ones. Of course, this behavior is somewhat constrained by the political costs that fall on the prosecutor when she takes cases to trial and loses them. If she follows this strategy, however, she need not try many cases-just enough to make the threat credible - and she need only win a few for the strategy to become quite credible. Quite obviously, the social costs of this strategic behavior are exacerbated if among these defendants are those who are factually innocent but unable to so signal during plea bargaining. Thus, a defendant like Hayes (especially if innocent) would be better off if the prosecutor could not bargain at all: in that event, the prosecutor would probably drop the recidivist charge, since she would get nothing out of it.

In short, where the legislature drafts broad criminal statutes and then attaches mandatory sentences to those statutes, prosecutors have an unchecked opportunity to overcharge and generate easy pleas, a form of strategic behavior that exacerbates the structural deficiencies endemic to plea bargaining. Because this difficulty arises from the conjunction of several factors, it is possible to avoid it in any of several different ways. ${ }^{179}$ Reducing overbreadth in criminal statutes is the most obvious possibility. If virtually all of the behavior that falls within a given statute merits the mandatory sentence the legislature attaches, then the strategic problem disappears. But reducing overbreadth has its costs: it occupies prosecutors and courts with detailed elements of detailed crimes, thereby increasing the expense of trial. Alternatively, one might do away with the type of mandatory sentencing used in Bordenkircher. This too can be costly. Legislatures might feel that politically unresponsive judges are too lenient. If the legislatures are right, mandatory sentencing is a valuable corrective. Indeed, it is the only means by which society can prevent an unelected ${ }^{180}$ judiciary from thwarting its will.

But solving the Bordenkircher problem does not require the elimination of all mandatory sentencing; the problem stems only from mandatory sentences that attach to overbroad criminal statutes. A different type of system, one that uses more complex formulas, as opposed to the mechanical attachment of a

179. One could argue that the Bordenkircher problem justifies dispensing with plea bargaining altogether. This option has something of a baby-and-bathwater difficulty, however, since cases like Bordenkircher are likely to be a fairly small minority of the overall docket. After all, the most common complaint about plea bargaining outside academic circles is that it leads to underpunishment. If Hayes were the typical defendant, that sentiment surely would not be so widespread. Absent some showing that the pricing/duress problem is otherwise unsolvable, or that it infects at least a large minority of criminal cases, abolition of plea bargaining seems too extreme a response.

180. Where judges are elected, the case for mandatory sentencing is much weaker. 
given number of months or years to a given statute, would be much harder for prosecutors to manipulate because it would generate far less overbreadth.

Such a system presently exists. The federal sentencing guidelines, ${ }^{181}$ for all the criticism they have attracted, ${ }^{182}$ have largely succeeded in both drastically reducing judicial sentencing discretion and preventing prosecutors from imposing (or threatening) unintended criminal liability on marginal defendants who fall within broad statutes. The guidelines accomplish this by using formulas that focus on the presence or absence of numerous aggravating and mitigating factors, and by gearing sentences to the harm caused by the particular criminal event. Drug defendants, for example, are sentenced (in part) according to the amount they possessed, not solely according to which statute they violated. By drawing more lines, the guidelines diminish overbreadth. ${ }^{183}$

Of course, the sentencing guidelines may have other problems-in particular, they may make bad policy choices about particular crimes. But that is a problem of sentencing policy, one that will exist whether plea bargaining exists or not. In plea bargaining terms, the guidelines suggest a way of avoiding both judicial arbitrariness and prosecutorial advantage-taking. When combined with the other reforms we have suggested in this part, they offer a useful model for a system that provides sentencing predictability without generating strategic bargaining.

\section{CONCLUSION}

The central problem with both sides of the plea bargaining debate is the same: they do not take contract seriously enough. Both at the level of broad abstraction-is plea bargaining defensible in principle?-and at the level of doctrinal detail-how and when should prosecutorial promises be enforced?-contract law and theory have a great many useful insights for this pervasive, and pervasively criticized, practice. At the broadest level, contract

181. See Sentencing Reform Act of 1984, Pub. L. No. 98-473, 98 Stat. 1987 (1984) (codified as amended at 18 U.S.C. §§ 3551-3559, 3561-3566, 3571-3574, 3581-3586 (1988), and 28 U.S.C. \$§ 991-998 (1988)); U.S. SENTENCING COMM'N, FEDERAL SENTENCING GUIDELINES MANUAL (1992).

182. The most vociferous critics are the judges, e.g., Gerald W. Heaney, The Reality of Guidelines Sentencing: No End to Disparity, 28 AM. CRIM. L. REV. 161 (1991), for whom the guidelines represent a significant loss of authority. Academics have been largely critical as well. See Albert W. Alschuler, The Failure of Sentencing Guidelines: A Plea for Less Aggregation, 58 U. CHI. L. REV. 901 (1991); Proposed Sentencing Guidelines for United States Courts, 52 Fed. Reg. 3920, 3986 (1987) (dissenting view of Commissioner Paul H. Robinson).

183. Of course, there is still some overbreadth; it is easy to come up with horror stories in which two incidents that yield very different culpability judgments nevertheless get the same sentence under the guidelines. See, e.g., Alschuler, supra note 182, at 918-24. But there are three responses to those homor stories. First, most of them stem from bad sentencing policy judgments rather than overbreadth. Second, similar horror stories could be told in discretionary sentencing jurisdictions, only there the difference would be produced not by law, but by acts of judicial discretion. The relevant question is not whether the guidelines are perfect, but whether they are better than the alternative. Third and finally, the degree of overbreadth under the guidelines is of a much lesser magnitude than the overbreadth generated by mandatory recidivist statutes of the sort involved in Bordenkircher. 
provides a framework for thinking about when consensual allocation ought to be permitted. That framework offers a fairly clear answer to the most basic questions policymakers (legislative or judicial) might want answered. In contract terms, plea bargains do not amount to duress; they are not, in general, unconscionable; they do not have the key characteristics of slavery contracts; and they are distributionally fairer than the likely alternative. Given the range of areas where our legal system tolerates (indeed, subsidizes) consensual allocation, it is hard to argue that contract is impermissible here. Seeing plea bargaining as contract thus helps one understand why the lawyers and judges who engage in and regulate the practice seem so comfortable with it.

But while consensual allocation has the same virtues here as elsewhere, it has an important flaw, one that infects not only plea bargaining but many other features of the criminal justice system. Innocent defendants have a hard time signaling their innocence in ways that guilty defendants cannot copy. This is not true of all stages in the process-police interrogation, for example-but it is true of plea negotiations. The upshot is that prosecutors have good reason to underestimate the odds that any given defendant might be innocent. This might not be a problem if trials were perfect, but of course they are not. And the consequences of this structural difficulty are likely to be substantial because of innocent defendants' risk aversion, a characteristic that may lead them to accept deals that do not discount for the possibility of acquittal. Understanding the bargaining dynamic of plea negotiations thus helps explain the discomfort so many outside observers feel about them.

Current legal doctrine not only fails to solve that structural problem (solutions may not exist); it makes the problem worse. By failing to enforce prosecutors' sentencing promises, the law encourages courts to raise sentences in precisely those cases where the defendant is most likely to be innocent. By underprotecting against defense attorney error, the law increases the chances of risk averse innocent defendants accepting deals that treat them as certain convictions. And by permitting prosecutorial manipulation of broad mandatory sentencing statutes, the doctrine reduces prosecutors' incentives to separate innocent from guilty defendants at the charging stage. All these effects are unnecessary. By following appropriate contract models, one can devise different rules that reduce the harm to innocent defendants and meanwhile reduce transaction costs and inefficiency for everyone else.

The puzzle is that these systemic doctrinal problems have persisted so long, with so little attention. The reason, we think, has to do with the nature of the plea bargaining debate. Though it has long been understood that plea bargaining is a species of contract, the debate about it has been framed not in the language of bargains, but chiefly in the language of rights. That may have something to do with its either-or character: either the defendant's rights trump the bargain or the rights do not apply; either plea bargaining is wholly impermissible or it raises no constitutional (read: important) issue. Rights rhetoric has led to a 
great deal of discussion of whether plea bargaining is a good thing, but little attention to what the law that surrounds it ought to look like.

The time has come to put rights talk to one side and view plea bargaining through the lens of contract. Contract makes the positive reactions of plea bargaining participants seem sensible, for plea bargains are indeed paradigmatically value-enhancing bargains. Contract makes the disquiet of the critics seem sensible too, since the bargaining dynamic shortchanges the innocent. And contract offers a range of second-best solutions, doctrinal reforms that can help prosecutors and defendants alike. These kinds of solutions may be less interesting than grand constitutional theory. In this context, they may also be more useful. 